\title{
Physical Stratigraphy of the Genesee Formation (Devonian) in Western and Central New York
}

GEOLOGICAL SURVEY PROFESSIONAL PAPER 1032-A

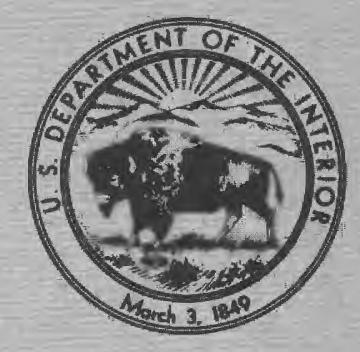





\section{Physical Stratigraphy of the Genesee Formation (Devonian) in Western and Central New York}

By WALLACE de WITT, JR., and G. W. COITON

STRATIGRAPHY AND CONODONTS OF

THE GENESEE FORMATION (DEVONIAN)

IN WESTERN AND GENTRAL NEW YORK

GEOLOGICAL SURVEY PROFESSIONAL PAPER 1032 -A

West of Cayuga Lake, the Genesee Formation thins by transgression on the Algonquin arch, as is shown by stratigraphic sections and conodont biostratigraphy

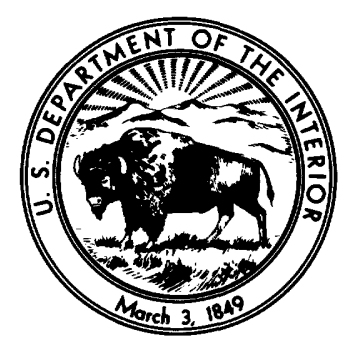




\title{
UNITED STATES DEPARTMENT OF THE INTERIOR
}

\author{
CECIL D. ANDRUS, Secretary
}

\section{GEOLOGICAL SURVEY}

H. William Menard, Director

Library of Congress Cataloging in Publication Data

de Witt, Wallace, Jr., 1920-

Physical stratigraphy of the Genesee Formation (Devonian) in western and central New York.

(Stratigraphy and conodonts of the Genesee Formation (Devonian) in western and central New York) (Geological Survey professional paper; 1032-A)

Includes bibliographical references.

Supt. of Docs. no.: I 19.16:1032A

1. Geology, Stratigraphic-Devonian. 2. Geology- New York (State) I. Colton, George Willis, 1920- joint author. II. Title. III. Series. IV. Series: United States. Geological Survey. Professional paper; $1032-A$. QE665.D49 551.7'4 $77-608020$

For sale by the Superintendent of Documents, U.S. Government Printing Office

Washington, D.C. 20402

Stock Number 024-001-03087-0 


\section{CONTENTS}

Abstract
Introduction
Purpose of report
Rocks below the Genesee Formation
$\quad$ Geneseo Shale Member
Penn Yan Shale Member
Sherburne Flagstone Member
Renwick Shale Member
Ithaca Member
Genundewa Limestone Member
West River Shale Member
Environment of deposition
Rocks above the Genesee Formation
Sonyea Formation -
References cited -

\section{ILLUSTRATIONS}

[Plates are in separate case]

Plate 1. Map showing the outcrop of the Genesee Formation in western and central New York

2-6. Stratigraphic section of the Genesee Formation and contiguous rocks:

2. From Lake Erie to Canandaigua Lake, New York.

3. From Canandaigua Lake to Tully, Onondaga County, New York.

4. In the vicinity of Canandaigua and Keuka Lakes, New York.

5. From Penn Yan, Yates County, to Cayuga Inlet near Ithaca, Tompkins County, New York.

6. In the Genesee Valley and across the northern arms of Keuka Lake, New York.

FIGURE 1. Index map showing the outcrop of the Genesee Formation in western and central New York

2. Isopach map showing thickness of the Genesee Formation

3. Isopach map showing thickness of the Geneseo Shale Member

4. Isopach map showing thickness of the Penn Yan Shale Member

5. Isopach map showing thickness of the Sherburne Flagstone Member

6. Diagram showing trends of siltstone-filled scour channels in the Renwick Shale Member ..........

7. Isopach map showing thickness of the Renwick Shale Member

8. Isopach map showing thickness of the Ithaca Member

9. Isopach map showing thickness of the West River Shale Member

\section{TABLE}

1. Location of measured sections of the Genesee Formation in western and central New York and the thickness of stratigraphic units present 


\title{
STRATIGRAPHY AND CONODONTS OF THE GENESEE FORMATION (DEVONIAN)
} IN WESTERN AND CENTRAL NEW YORK

\section{PHYSICAL STRATIGRAPHY OF THE GENESEE FORMATION (DEVONIAN) IN WESTERN AND CENTRAL NEW YORK}

\author{
By Wallace de Witt, JR., and G. W. Colton
}

\begin{abstract}
The Genesee Formation of western and central New York is the basal Upper Devonian unit in the classic reference section for the Devonian in North America. We measured many sections in detail by planetable methods and mapped key beds, members, and formations in an area from Lake Erie east to Tully, Onondaga County, and south to the State line. Because the Genesee, like several overlying Upper Devonian formations, is composed of intertonguing cyclically recurring facies, we were obliged to revise the existing stratigraphic nomenclature by redefining some existing units and establishing reference sections for others.

The Genesee Formation includes all rocks between the top of the Tully Limestone east of Canandaigua Lake, or the top of the Moscow Shale west of Canandaigua Lake where the Tully is absent, and the base of the Middlesex Shale Member of the Sonyea Formation.

The Genesee Formation is about 9 feet thick at Lake Erie in western New York, where we recognize three members in ascending order: Penn Yan Shale, Genundewa Limestone, and West River Shale. Locally in Erie County, the North Evans Limestone of Rickard (1964) is present in the lower part of the Genesee. The Genesee thickens to the east and southeast.

The Geneseo Shale Member, an eastward-thickening tongue of black shale, is the basal unit of the formation. In the area west of Keuka Lake, the Genesee Formation is composed mainly of dark mudrock and shale, subordinate amounts of argillaceous limestone nodules or beds, and a scattering of thin-bedded quartzose siltstone.
\end{abstract}

At and east of Keuka Lake, east-thickening tongues of medium- to light-gray thin-bedded to massive quartzose siltstone, the Sherburne Flagstone Member and the Ithaca Member, wedge into the more seaward facies of the Genesee Formation. The Ithaca Member is present at Keuka Lake, whereas the Sherburne Flagstone Member extends only as far west as the south end of Seneca Lake. From Cayuga Lake eastward to Skaneateles Lake, the Renwick Shale Member, a sequence of brownish-black shale and intercalated channel-filling siltstone separates the older Sherburne Flagstone Member from the younger Ithaca Member.

The Genesee Formation is about 900 feet thick at Cayuga Lake, where it is composed of the following members in ascending order: Geneseo Shale Member, Penn Yan Shale
Member, Sherburne Flagstone Member, Renwick Shale Member, Ithaca Member, and West River Shale Member. East of Cayuga Lake, most of the shale members intertongue with siltstone facies, and at the meridian of Tully, only the Geneseo Shale Member at the base of the formation is recognized below a thick sequence of the undivided Sherburne Flagstone and Ithaca Members.

The Genundewa Limestone Member, readily identified by its abundant Styliolina fauna, is present from Lake Erie east to Shuman Cemetery near Gorham, north of Keuka Lake. At Shuman Cemetery, the eastern featheredge of Genundewa underlies the western tip of an extensive tongue of siltstone and subordinate very fine grained sandstone, the Crosby Sandstone of Torrey and others (1932). Their Crosby lies near the middle of the Ithaca Member southeast of Keuka Lake, and the correlation of Genundewa with the Crosby establishes the relation of middle Genesee units from Lake Erie to Cayuga Lake. Similarly, a thin convolutely-bedded turbidite, the Bluff Point Siltstone Bed, is commonly present in the middle of the West River Shale Member from the west side of Seneca Lake across western New York to Eighteenmile Creek at Lake Erie. The stratigraphic position of the widespread and distinctive Bluff Point Siltstone Bed of the West River tends to corroborate the Genundewa-Crosby correlation.

The Genesee sediments accumulated in the deeper part of an epicontinental sea west of the Late Devonian Catskill Delta. Although the upper waters of the sea were clear and well oxygenated, a euxinic environment existed in the deeper part of the sea during much of Genesee time. Here depositional energy was low, and only the finer grained sediments accumulated in the quiet water. Distal tongues of turbidites from the growing delta extended into westcentral New York and came to rest intercalated with brownish-black mud rich in organic detritus. Local pulses of higher depositional energy, exemplified by the Bluff Point Siltstone Bed of the West River, overran much of the western part of the study area; however, most of the turbidity flows ran out of energy in the area east of Keuka Lake. Shoaling of the sea and the shift of environments to higher depositional energy and coarser grained deposits are suggested by the increased number and thickness of more proximal turbidites in much of the Genesee Formation along the Tioughnioga Valley at the east side of the study area. 


\section{INTRODUCTION}

The area of this report covers parts of 14 counties in central and western New York and includes much of the Finger Lakes district, Genesee River valley, and a little of the south shore of Lake Erie (fig. 1). Western New York has long been a classic reference for the Upper Devonian sequence in North America. The strata in this area, particularly the lower Upper Devonian rocks of the Finger Lakes district, have been studied by many geologists during the past 130 years. Knowledge of the stratigraphy in the area evolved slowly because of the scarcity of well-exposed sections and the complex interfingering of petroliferous brownish-black shale, calcareous gray shale or mudrock, silty gray shale and mudrock, silty shale, siltstone, and finegrained sandstone. We (de Witt and Colton, 1959) have briefly summarized the history and correlation of the Genesee and related rocks.

The work upon which our report is based was part of a study, of the petroliferous black shales of Late Devonian age, initiated by J. F. Pepper in 1947. During the course of the work, which continued intermittently until 1964, Pepper, Colton, and de Witt measured more than 400 stratigraphic sections in great detail by planetable and telescopic alidade. Many other sections were measured with steel tape, and the elevations of key beds were determined by planetable or with a precise surveying altimeter. Local and regional correlations were established by matching lithologic sequences in contiguous exposures and by mapping or projecting key beds and stratigraphic sequences across the study area. Where possible, units were projected into the subsurface of southwestern New York and correlated with stratigraphic sequences found in deep wells drilled for oil or gas. Structure maps drawn on the Tully Limestone and on conspicuous key beds within the Upper Devonian sequence were constructed to aid in projecting units across covered intervals and into the subsurface south of the outcropping Genesee Formation.

Wilbert $\mathrm{H}$. Hass began a study of the conodont faunas in the Upper Devonian strata as a adjunct to our stratigraphic work in western New York. Hass died in 1959, before completing much of his study, and John W. Huddle continued the study as time permitted in the following years.

Although prevented by failing health and the demands of other duties from participating in the fieldwork on the Genesee Formation, Pepper followed our progress with keen interest and was able to see most of the stratigraphy roughed out before his death in 1963.

During our study of the Genesee Formation, we were assisted at different times by M. J. Bergin, J. P. D'Agostino, J. R. Elizondo, J. H. Hambleton, J. E. Johnston, Murray Levish, and Henry Stipp. We thank W. T. Kirchgasser and the late J. W. Huddle for critical review of this report.

Western and central New York were strongly glaciated during the Pleistocene by continental ice sheets. Although some of the topography was considerably modified by scour and erosion, particularly along main drainage lines in the vicinity of the Finger Lakes and Lake Erie, deposition generally was much greater than erosion. Thick sheets of till or glaciofluvial debris blanket much of the area and locally, as at Watkins Glen, filled the deeply incised valleys south of the lakes with as much as 1,200 feet of glacial sediment. Because of the extensive cover of glacial debris, the Devonian bedrock is rarely exposed, except in the cliffs along lakeshores or along the steep-walled valleys of postglacial streams that have cut through the mantle of younger sediment. The scarcity of outcrops greatly hindered mapping in western New York, and the correlation of similar-appearing but nonequivalent facies led to much stratigraphic confusion in the past (de Witt and Colton, 1959, fig. 2).

The paucity of outcrops and the subtle local variations in the gentle south regional dip necessitated detailed measurement of most long exposures. Detailed mapping was commonly required to bridge broad areas of glacial drift between well-exposed sections along the larger streams, particularly in the western part of the area between Lake Erie and the hilly tracts bordering the Genesee River and the smaller Finger Lakes. Outcrops are more abundant near the larger Finger Lakes in the eastern half of the area, and some relatively thin but extensive key beds, for example, the Bluff Point Siltstone Bed of the West River Shale Member of the Genesee, can be traced widely in many of the stream gullies near Keuka and Canandaigua Lakes (pls. 1,4 , and 6). South and east of a line from Tully, Onondaga County, to Ithaca, Tompkins County, outcrops are relatively poor, except locally along the Tioughnioga River and its tributaries. Most of the high well-rounded hills in the southern part of the mapped area lack long continuous exposures of bedrock.

Where possible, we supplemented surface data with subsurface data from descriptions of drill cut- 
PHYSICAL STRATIGRAPHY

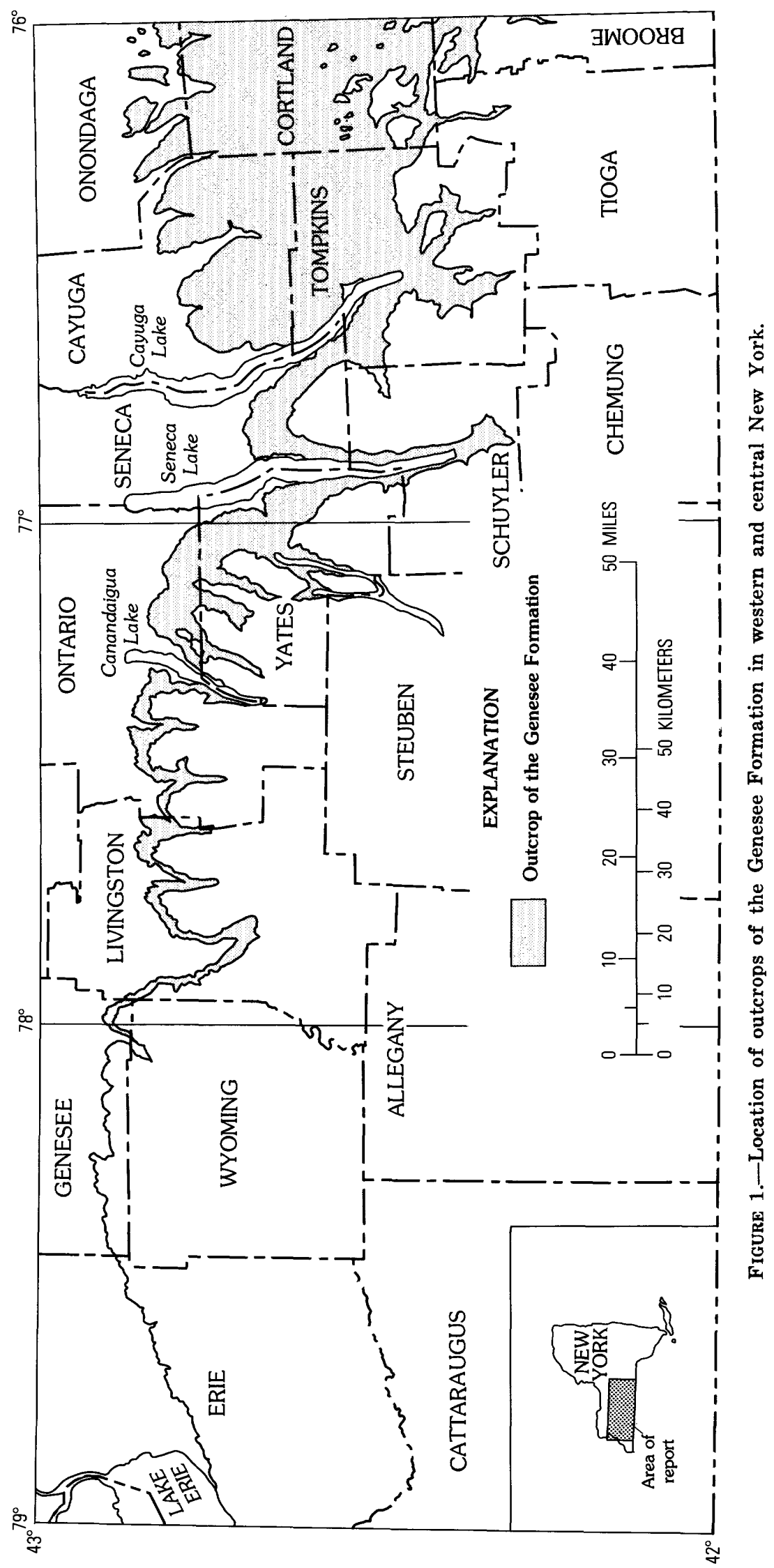


tings from scattered deep wells drilled for gas or oil. These subsurface data permitted compilation of structure maps and isopach maps of the Genesee Formation and some of its members. The combination of surface data, structure, and isopach maps greatly facilitated locating and tracing key beds and units in the Genesee Formation in the area east of Seneca Lake, where the Genesee contains a great thickness of silty shale and thick-bedded massive siltstone.

\section{PURPOSE OF REPORT}

The purpose of this report is to present much of the detailed data on the internal stratigraphy of the Genesee Formation that we were unable to include in our brief report in 1958 . The report also provides the detailed stratigraphic framework for the associated discussion of the conodont faunas of the Genesee Formation and contiguous rocks. During our study, we often had difficulty relocating and recovering sections mentioned by previous workers, especially the sections cited by James Hall and his followers more than 100 years ago. Changes in local place names and the disappearance of oncethriving communities introduced ambiguities that could not always be resolved. We hope that the location of our measured sections (pl. 1 and table 1) will facilitate reexamination of these sections by interested geologists.

\section{ROCKS BELOW THE GENESEE FORMATION}

From the place where it rises above the level of Lake Erie about a half mile west of the mouth of Pike Creek (SC-1, pls. 1, 2, and 3) and eastward to the vicinity of Gage Gully ( $\mathrm{Cd}-12)$, the Genesee Formation is underlain by the Moscow Shale (Hall, 1839, p. 298), a sequence of medium-gray $(N 5)^{1}$ to medium-dark-gray $(N 4)$ fossiliferous calcareous mudrock. Ovoid, discoid, and irregularly ramose argillaceous limestone nodules are locally abundant in the Moscow. At places, the nodules coalesce to beds of impure limestone as much as 5 feet thick (Cazenovia Creek, Dp-1, pl. 2). Small nodules and lenses of pyrite occur commonly in the upper part of the Moscow, and locally some beds of dark-grayish to brownish-black shale (N2 to $5 Y R$ $2 / 1$ ) are intercalated in the formation. In the area between Pike Creek (SC-1) and Cazenovia Creek (Dp-1), a nodular bed of conodont-bearing argillaceous limestone as much as 0.15 foot thick, the Conodont bed of Hinde $(1879$, p. 352) or North Evans Limestone of Rickard (1964, chart 1), is

1 Colors keyed to the "Rock-Color Chart" (Goddard and others, 1948). found at the top of the Windom Member of the Moscow Shale (Grabau, 1917, p. 946; Cooper, 1930, p. 232) ; locally at Clover Bank (Ed-2) it directly underlies the Genundewa Limestone Member of the Genesee Formation. Although these two carbonate units are locally in contact, their conodont faunas demonstrate a hiatus that is equivalent to as much as 125 feet of beds at Canandaigua Lake (Cd-7).

At many places between Pike Creek (SC-1) and Gage Gully (Cd-12), lenticular masses of abundantly fossiliferous pyrite as much as 0.6 foot thick and 1-10 feet long are present at the contact between the Moscow Shale and the Genesee Formation. Collectively, these lenses of pyrite are the Tully pyrite of Loomis (1903, p. 893) and the Leicester Marcasite Member of the Moscow Formation of Sutton (1951, p. 379). The age of the Leicester has been in question for a considerable time. Because in most outcrops, the lenses of pyrite are above the gray mudrock of the Moscow and at the base of the black shale (N2) or brownish-black mudrock $(5 Y R 2-3 / 1)$ of the Genesee, the Leicester could be assigned to either unit. At Gage Gully (Cd-12) at the base of the Genesee Formation, we found nodules of pyrite of the Leicester-type half an inch thick and 0.5-1.5 feet long on nodules of Tully Limestone 0.8 foot thick and 2 feet long. The nodules of Tully Limestone, which contain Hypothyridina venustula, are the western featheredge of the main sheet of Tully (pl. 3). Clearly at Gage Gully, the Leicester is younger than Tully Limestone and the subjacent Moscow Shale. To the west, the age of the Leicester is equivocal because the Tully is absent, and, according to Cooper (1930, p. 122), the uppermost part of the Moscow Shale is progressively older westward across western New York.

The Moscow Shale, like many other units in the Devonian of New York, thins to the west and thickens to the east. The top of the Tichenor Limestone of Clarke (1903, p. 22; Cooper, 1930, p. 226), which marks the base of the Moscow Shale, is exposed at water level at the mouth of Pike Creek (SC-1) and is 11 feet below the base of the Genesee Formation. At Elevenmile Creek (At-1), about 33 miles to the east, the Moscow has thickened to $\mathbf{5 5}$ feet (pl. 2).

From the east side of Canandaigua Lake eastward to Tully (pl. 3), the Genesee Formation is underlain by the thick-bedded to massive cobblyweathering fossiliferous Tully Limestone. The Tully (Vanuxem, 1839, p. 278) is generally a slightly argillaceous, dark-gray (N3) to grayish-black 
(N2), bluish-gray $(5 B \quad 4 / 1)$ to $\tan (5 Y 7 / 1)$ weathering calcilutite with some interbedded calcarenite and wispy laminae of quartz silt. Locally at Borodino (Heckel, 1973, p. 45-53), the Tully contains abundant encrinal beds intercalated in a mound complex. Throughout much of its extent, the Tully contains many fossils, although their presence may be obscured by the cobbly weathering. Cooper and Williams (1935) and Heckel (1973, p. 14-16, App. B) gave detailed accounts of the fauna of this formation.

The resistant Tully generally forms the massive capstone of falls and cascades along its outcrop. Commonly, the formation is poorly exposed between streams, but locally on the hilltops near Tully and between Cayuga and Skaneateles Lakes, the limestone crops out sparsely in fields and ditches.

The Tully thickens from a zone of nodules about 0.8 foot thick at Gage Gully $(\mathrm{Cd}-12)$ to about 25 feet in the vicinity of Tully $(\mathrm{Tu}-1, \mathrm{Tu}-4)$. Subsurface data show that the formation thickens to. the south and reaches a maximum of more than 200 feet in the vicinity of Lock Haven, Pa. (Heckel, 1973, fig. 14). The Tully is readily identified in well cuttings, and it makes a good marker unit for subsurface work. Our subsurface correlations of the Genesee Formation in much of south-central New York are based upon the presence of the massive resistant Tully Limestone just below the black shale of the Geneseo Shale Member of the Genesee Formation.

The upper contact of the Tully is sharp and appears conformable from the eastern side of Canandaigua Lake to Cayuga Lake. The uppermost massive bed of the Tully is abruptly overlain by brownish-black $(5 Y R$ 2/1) shale of the Geneseo Shale Member. East of Cayuga Lake, the Tully is overlain by limestone and shale interfingering in a zone as much as 15 feet thick and consisting of brownishblack $(5 Y R 2 / 1)$ slightly calcareous shale in 1 - to 6 -inch beds intercalated with argillaceous brownish-black $(5 Y R \quad 2 / 1)$ to olive-black $(5 Y \quad 2 / 1)$ nodular limestone in beds $3-18$ inches thick. Commonly, the argillaceous limestone does not resemble the subjacent cobbly weathering Tully. It weathers in irregular plates and slabs and is lithologically similar to the lenticular beds of coalesced limestone nodules that are present higher in the black or darkbrown shale of the Genesee. We (de Witt and Colton 1959 , p. 2820) included the sequence of transitional beds in the Genesee Formation because they are lithologically unlike the Tully and are separated from the massive cobbly weathering Tully by brownish-black $(5 Y R 2 / 1)$ shale similar to the main body of the Geneseo Shale Member, the basal member of the Genesee Formation (pl. 3). Heckel (1973, p. 9), however, presented data that led him to include these beds in his Tully Limestone. On physical evidence, we believe that the transitional beds belong in the Genesee Formation rather than in the Tully Limestone.

\section{GENESEE FORMATION}

In 1959, we (de Witt and Colton, 1959, p. 2815) defined the Genesee Formation to include all the strata between the Tully Limestone below and the Middlesex Shale Member of the Sonyea Formation above in the area between Tully, Onondaga County, and Gage Gully ( $\mathrm{Cd}-12)$ on the east side of Canandaigua Lake where the Tully Limestone pinches out (pl. 3). West of Canandaigua Lake, the Genesee Formation is overlain by the Sonyea Formation and underlain by the Moscow Shale (pl. 2). Prior to this redefinition, the strata included in our Genesee Formation had been included partly in the Genesee Shale of Clark and Luther (1904, p. 19), partly in the Portage Formation of Hall $(1840$, p. 391$392,452-455$ ), and partly in the Genesee Group of Chadwick (1933, p. 96). The history of the usage of the name Genesee is relatively complicated and will not be discussed here.

In the area west of Canandaigua Lake, the Genesee is composed largely of black (N1), grayish-black (N2) to olive-black (5Y 2/1) shale and dark- to medium-gray ( $N 3$ to $N 5$ ) shale or mudrock; in addition, the formation contains small amounts of nodular limestone, argillaceous siltstone, and an abundance of intercalated limestone nodules of many shapes and sizes. Four members are recognized. In ascending stratigraphic order, they are the Geneseo Shale Member, the Penn Yan Shale Member, the Genundewa Limestone Member, and the West River Shale Member (pl. 2). Tongues of siltstone and shaly siltstone wedge into the Genesee Formation between Canandaigua Lake and Cayuga Lake. The change from predominantly shale and mudrock to predominantly siltstone is well shown in sections along streams tributary to Seneca Lake between Dresden and Watkins Glen (pl. 5). In the vicinity of Ithaca at the south end of Cayuga Lake, two thick units of siltstone and an intercalated tongue of dark shale-the Sherburne Flagstone Member, the Renwick Shale Member, and the Ithaca Member-separate the Penn Yan Shale Member from the West River Shale Member (pls. 3 and 5). The Genesee Formation is composed mainly of siltstone, shaly siltstone, and silty shale from 
Cayuga Lake to the east edge of the area studied.

The Genesee Formation is about 9 feet thick where it plunges below the level of Lake Erie about half a mile west of the mouth of Pike Creek (SC1). The formation thickens eastward to about 130 feet near Geneseo (pl. 6), about 250 feet at Canandaigua Lake (pls. 2 and 3 ), and more than 940 feet near Ithaca (pl. 5). The Genesee thickens to the southeast in the subsurface and is more than 1,200 feet thick along the State line southeast of Elmira (fig. 2). As the Genesee Formation thickens to the south in the subsurface, the shaly units thicken, and in north-central Pennsylvania the Genesee merges into and its identity is lost in a great mass of very dark gray to brownish-black slightly silty shale containing scattered beds of very dark gray to medium-gray siltstone.

The upper boundary of the Genesee Formation is placed at the base of the widespread grayishblack (N2) to brownish-black $(5 Y R 2 / 1)$ shale of the Middlesex Shale Member of the Sonyea For- mation (Colton and de Witt, 1958). The contact is sharply marked and conformable throughout the area west of Ithaca, where the gray shale and intercalated thin-bedded siltstone in the upper part of the West River Shale Member of the Genesee contrast markedly with the overlying black shale in the Middlesex Shale Member of the Sonyea. East of Ithaca, in parts of Cortland, Tioga, and Broome Counties, the Middlesex is relatively thin and rests upon thick-bedded siltstone and shaly siltstone in the upper part of the Ithaca Member, which mark the top of the Genesee Formation there. The boundary between the Genesee and the Sonyea Formations is clearly discernible at the change from siltstone to dark-brown silty shale but good exposures of the stratigraphic interval containing these beds are scarce.

\section{GENESEO SHALE MEMBER}

Chadwick (1920, p. 118) proposed the name Geneseo for 83 feet of "black" shale separating the Moscow Shale from the Genundewa Limestone at

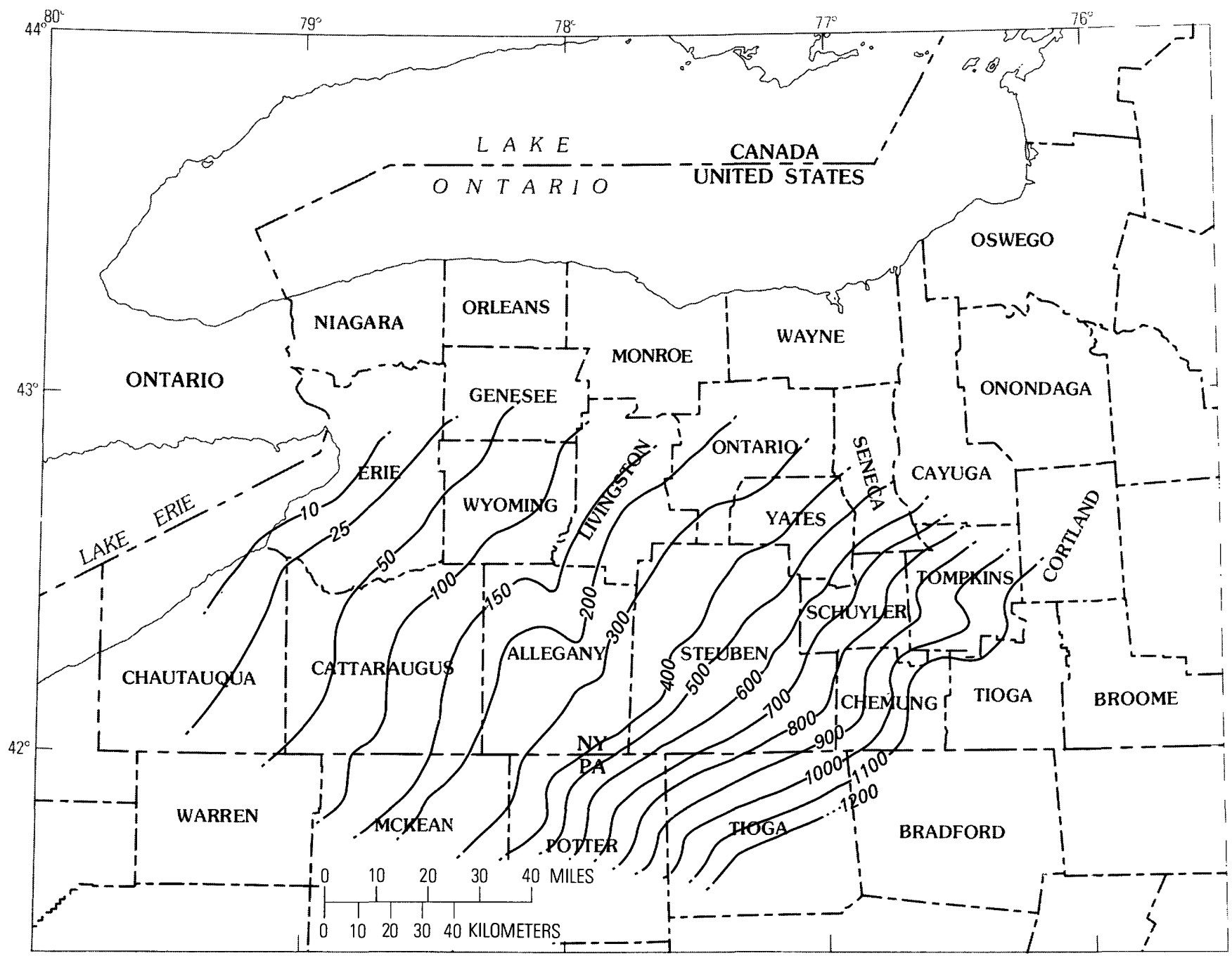

FIGURE 2.-Isopach map showing thickness of the Genesee Formation in feet. 
Fall Brook near Geneseo (Cl-4). We found, however, that much of the 83 feet of strata was darkgray massive mudrock and that only two beds of brownish-black shale, totaling $\mathbf{1 0 . 5}$ feet in thickness, might be traced east from Fall Brook into the thick black shale in the base of the Genesee Formation in the Finger Lakes district (pls. 2 and 3 ). Consequently, we restricted the name Geneseo to the two tongues of black shale in the lower part of the 83-foot sequence of Chadwick's Geneseo at Fall Brook and selected the 44 feet of black shale overlying the Moscow Shale at Menteth Gully (Cd-7) as the reference section for the Geneseo Shale Member of our Genesee Formation ( de Witt and Colton, 1959, p. 2816).

Kirchgasser (1975, p. 62) and L. V. Rickard (oral commun., 1974) indicated that the upper of the two beds of brownish-black shale at Fall Brook ( $\mathrm{Cl}-4)$ is not a tongue from the main mass of the black Geneseo Shale Member at Menteth Gully (Cd-7) ; rather, it is a discrete bed of black shale in the Penn Yan Shale Member. After considering their data, we are here restricting the name Geneseo Shale Member to the basal 5 feet of brownish-black shale in the Genesee Formation at Fall Brook (Cl-4) and are including the upper bed of brownish-black shale in the Penn Yan Shale Member ( $\mathrm{Cl}-4, \mathrm{pl} .2$ and pl. 6).

The Geneseo is composed predominantly of grayish-black (N2), brownish-black $(5 Y R 2 / 1)$, and olive-black $(5 Y 2-3 / 1)$ fissile shale. The rock is laminated and massive on fresh exposure and becomes fissile upon weathering. Commonly, it weathers to small sharp-edged chips or plates stained reddish brown or orange by limonite derived by weathering of contained pyrite. Locally, beds of very dark gray (N2-N3) or brownish-gray $(5 Y R 3 / 1)$ shale are intercalated in the Geneseo mainly in the upper part of the member in the western part of the mapped area. Grayish-black (N2) slightly argillaceous limestone nodules, which weather medium gray to medium light gray (N5$N 6$ ), are locally abundant in zones in the Geneseo. The nodules range in shape from spheroidal to discoidal and in diameter from half an inch to 3 feet. Many of the larger nodules show a septarian structure of white calcite and small amounts of barite, dolomite, ankerite, siderite, pyrite, and marcasite. Locally, the nodules coalesce to form lumpy-surfaced beds of argillaceous limestone 1-18 inches thick.

Medium-gray (N5) laminar to wavy-bedded siltstone in layers a quarter of an inch to 10 inches thick occurs sparingly in the Geneseo. Some beds of siltstone are calcareous and may contain scattered calcareous nodules, whereas other layers are noncalcareous and strongly resistant to erosion. The number of siltstone beds in the Geneseo increases eastward from Keuka Lake to the eastern border of the mapped area.

The Geneseo Shale Member forms the basal part of the Genesee Formation from the Tully quadrangle westward across the study area to the Depew quadrangle in eastern Erie County (pls. 2 and 3). The massive black shale is about 80 feet thick near Tully (Tu-1). It reaches its maximum thickness of about 130 feet in surface exposures at Glenwood Creek (I-1) and Taughannock Creek (Gen-5) northwest of Ithaca, and it thins westward to 44 feet at Menteth Gully (Cd-7). The Geneseo Shale Member is present at the base of the Genesee Formation as far west as Cayuga Creek (Dp-3), and it feathers out into dark-gray shale and mudrock of the Penn Yan Shale Member between Cayuga and Buffalo Creeks (Dp-2) (pl. 2).

The isopach map (fig. 3) shows the Geneseo Shale Member thickening rapidly from the east border of the mapped area to a maximum in parts of Chemung, Tompkins, Schuyler, and Steuben Counties. The member thins more gradually to the west and northwest and is absent in the western part of the mapped area.

Fossils are relatively scarce in much of the Geneseo Shale Member. However, in the area from Bellona ( $\mathrm{Ph}-7)$ eastward across the Ovid quadrangle and into the western part of the Genoa quadrangle to the Hubbard quarry adjacent to Lively Run (Gen-2), a small fauna of thin-shelled forms dominated by the inarticulate brachiopod Orbiculoidea lodiensis is found in the uppermost beds of the black shale of the Geneseo and in the basal dark-gray beds of the overlying Penn Yan Shale Member (Cole and others, 1959, p. 30). The interval containing Orbiculoidea lodiensis is thickest in the vicinity of Lodi $(\mathrm{Ov}-11)$ and Ovid (Ov15 and $\mathrm{Ov}-16)$; it thins to the east and west. We were unable to locate Orbiculoidea on the east shore of Cayuga Lake and in outcrops along the valley of Salmon Creek.

The upper boundary of the Geneseo Shale Member is generally well defined. The change from brownish-black (5YR 2/1) shale of the Geneseo into dark-gray (N4) or dark-brownish-gray (5YR $3 / 1$ ) slightly silty mudrock and shale of the Penn Yan Shale Member is abrupt at many places and can be readily noted, particularly in cliff sections where weathering accentuates the difference in types of rocks. Subsurface data show that south 


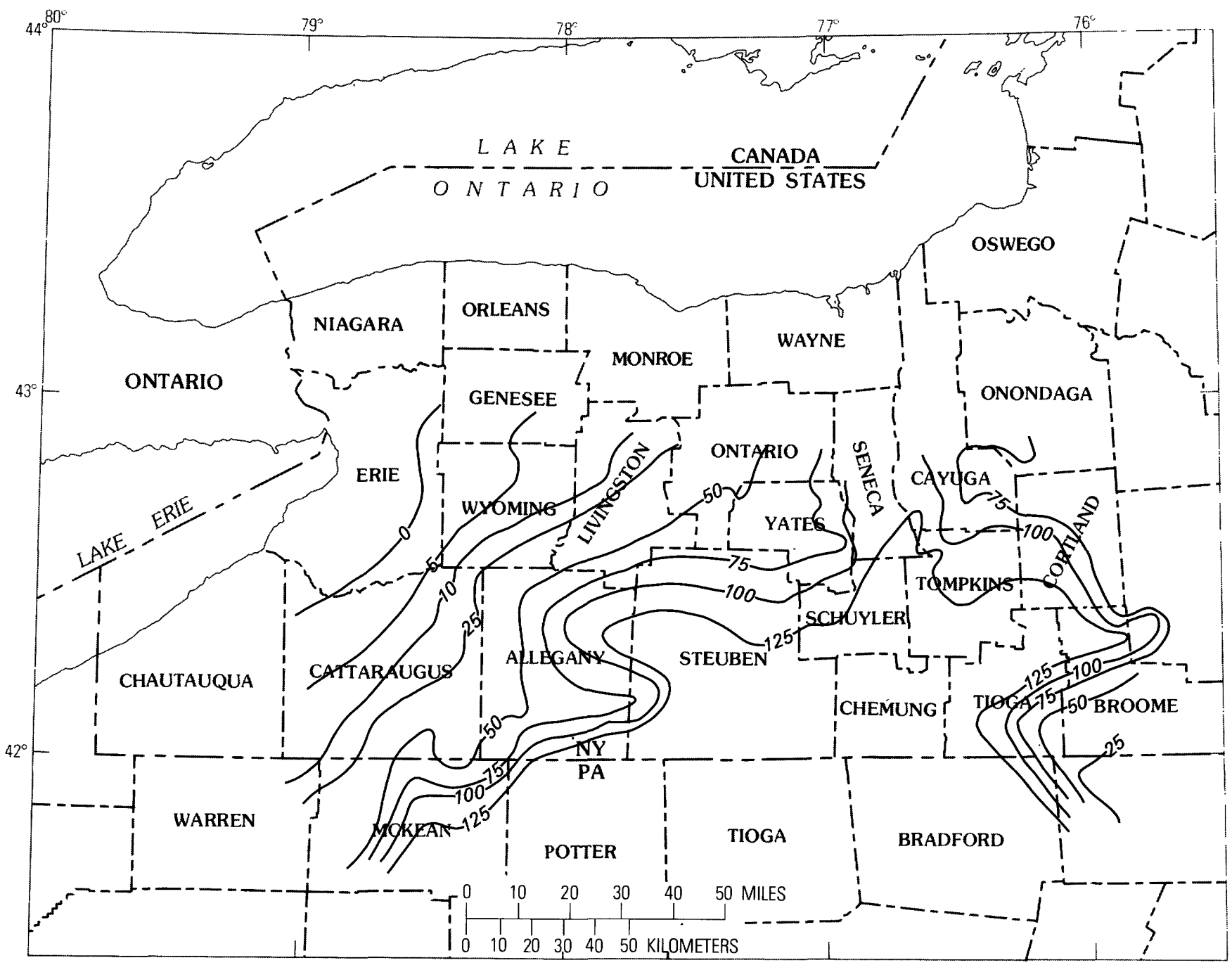

FIGURE 3.-Isopach map showing thickness of the Geneseo Shale Member in feet.

of Tully and east of Ithaca, the Penn Yan Shale Member grades laterally into the Sherburne Flagstone Member, and resistant thick-bedded siltstone of the Sherburne directly overlies the Geneseo Shale Member. The boundary between the Geneseo and Sherburne is marked by the change from silty brownish-black shale to medium-gray siltstone.

\section{PENN YAN SHALE MEMBER}

Grossman (1944, p. 64) gave the name Penn Yan to a 150-foot sequence of dark-gray mudrock and shale containing beds of black shale, calcareous nodules, and light-gray siltstone that overlies the Geneseo Shale Member and underlies the Crosby Sandstone of Torrey and others (1932, figs. 6 and 7 ) in stream gullies along the south side of Keuka Lake outlet in the vicinity of Seneca Mills (Py-12 and Py-13, pl. 4). Grossman believed that his Penn Yan beds were a tongue of the West River Shale of Clarke and Luther (1904, p. 28). Our study, however, showed that the Penn Yan rocks are separated from the West River Member of the Genesee Formation (de Witt and Colton, 1959, p. 2819) by the Genundewa Limestone Member, the Crosby Sandstone of Torrey and others, (1932), or by a thick wedge of clastic rocks, which include the eastern equivalent of the Genundewa (pls. 2, 3,4 , and 5). Consequently, we designated the Penn Yan a member of the Genesee Formation in 1959.

The Penn Yan Shale Member consists mainly of dark- to light-gray ( $N 3$ to $N 7$ ), olive-gray to lightolive-gray ( $5 Y 4 / 1$ to $5 Y 6 / 1$ ), and some greenishgray $(5 G Y 5 / 1)$ slightly silty mudrock and shale. Scattered beds of brownish-black (5YR 2/1) ironstained shale and a profusion of spheroidal to discoidal argillaceous grayish-black limestone nodules are interbedded in the Penn Yan. Scattered laminae and beds of siltstone 0.05 to 4 feet thick and ranging from nonresistant calcareous and argillaceous layers to resistant durable beds are intercalated in the member. Siltstones are fewest in the western part of the mapped area and increase in 
number and thickness eastward to the vicinity of Tully. Most of the beds of siltstone are relatively lenticular and of local extent, but some of the more massive beds are sufficiently extensive for shortrange correlation.

The Penn Yan Shale Member overlies the Geneseo Shale Member throughout the outcrop belt from Bucktail Falls $(\mathrm{Tu}-1)$ near Tully westward to Cayuga Creek ( $\mathrm{Dp}-3)$, where the Geneseo is overlapped. Westward to Lake Erie the Penn Yan facies rests upon the Windom Member of the Moscow Shale or on the North Evans Limestone of Rickard (1964, chart 4) (pls. 2 and 3). The Penn Yan is present below the Genundewa Limestone Member west to the vicinity of Buffalo Creek (Dp2) but is absent locally in the area between Buffalo Creek and Eighteenmile Creek (Ed-1). In cliffs at the mouth of Pike Creek (SC-1), a tongue of Penn Yan less than 1 foot thick separates the North Evans Limestone of Rickard (1964, chart 4) from the Genundewa Limestone Member of the
Genesee Formation. The Penn Yan thickens from less than 1 foot at Lake Erie to a maximum in outcrop of about 155 feet at the type section at Keuka Lake outlet (Py-13). East and southeast of the type exposure, the Penn Yan thins to 100 feet or less as the upper half of the member intertongues with and grades into the western part of a thick mass of siltstone, the Ithaca Member of the Genesee Formation (pl. 5). East of Seneca Lake, the part of the Penn Yan equivalent to the lower half of the member at Keuka Lake outlet intertongues with the Sherburne Flagstone Member, and the Penn Yan pinches out of the section as a recognizable unit in the Tully quadrangle (pl. 3). Subsurface data show that the Penn Yan Shale Member thickens south of the Finger Lakes and is more than 200 feet thick below Van Etten in northeastern Chemung County (fig. 4). In the subsurface, the member is thin in western New York and cannot be identified with certainty in western Cattaraugus and Chautauqua Counties.

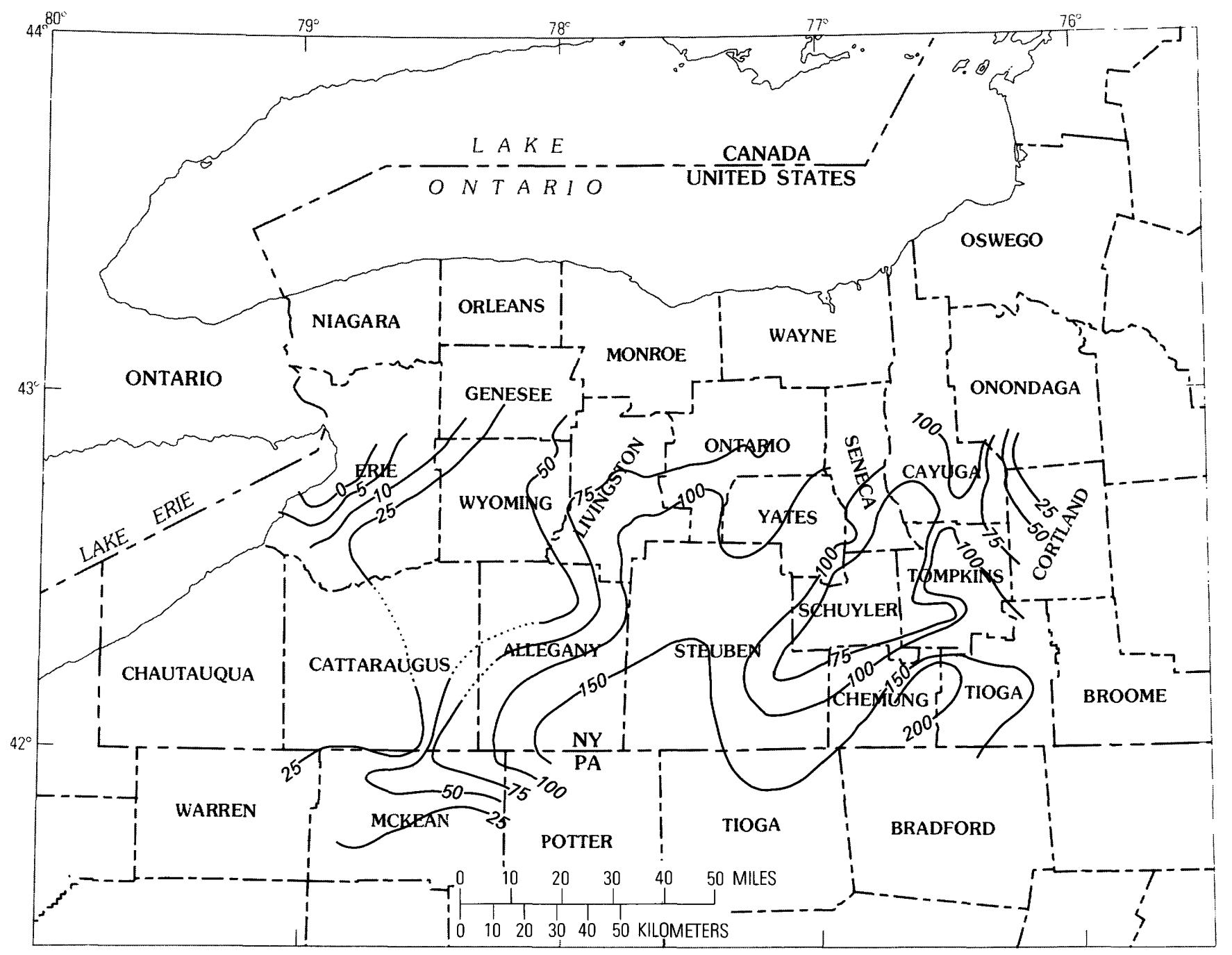

Figure 4.-Isopach map showing thickness of the Penn Yan Shale Member in feet. 
Thick-bedded calcareous or noncalcareous siltstone intercalated in the shaly Penn Yan at several localities has led to some vexing and erroneous correlations in the past. Several 2-foot-thick beds of argillaceous, calcareous, poorly bedded siltstone or very silty argillaceous limestone containing scattered spheroidal nodules of limestone and abundant Styliolina fissurella occur in the upper few feet of the Geneseo Shale Member and in the basal 10 feet of the Penn Yan Shale Member of Fir Tree Point (Wg-3) on the west side of Seneca Lake. Luther $(1909$, p. 27$)$ identified these siltstones as "Genundewa" because of their lithologic and paleontologic similarity to the Genundewa Limestone Member at Canandaigua Lake. He also identified as "Genundewa" a somewhat similar-appearing bed of silty argillaceous limestone that caps the Geneseo Shale Member about 6.5 miles north, in the vicinity of Baskins Point $(\mathrm{Ov}-4)$. Because both localities are well east of the eastern edge of the sheet of Genundewa as Luther knew it, he assumed that his "Genundewa" overlay his Genesee Shale, the unit we define as the Geneseo Shale Member, at Seneca Lake. Our study shows, however, that at Baskins Point and Fir Tree Point, Luther's "Genundewa" beds are about 180-220 feet below the Crosby Sandstone of Torrey and others (1932, figs. 6 and 7), which is the lateral equivalent of the Genundewa Limestone Member at Seneca and Cayuga Lakes (pls. 3, 4, and 5). They are not a part of the Genundewa Limestone of central and western New York. As a consequence of Luther's misidentification of the Genundewa at Seneca Lake, the Sherburne and Ithaca were thought to be younger than the Genundewa, but in fact the Sherburne and at least the lower third of the Ithaca at Seneca and Cayuga Lakes are older than the Genundewa.

Several beds of coalesced argillaceous limestone nodules and two or three thick-bedded layers of siltstone are found in the basal part of the Penn Yan and cap the Geneseo Shale Member in the area from Bellona $(\mathrm{Ph}-7)$ eastward across Seneca and Cayuga Lakes into the valley of Salmon Creek near Lansingville (Gen-9 to Gen-11). Some of these beds are within the interval containing Orbiculoidea lodiensis near Lodi, Ovid, and Hubbard's quarry. Outcrop data show that these resistant beds are lenticular and that individual beds have only local extent. They appear to be oldest in the eastern part of the area and youngest near Bellona at the west. Lincoln (1897, p. 101) noted a bed of silty argillaceous limestone nodules intercalated in calcareous argillaceous siltstone in Mill Creek at Lodi (Ov-10) at the top of our Geneseo Shale Member and described the fauna from it. The fauna became known as the Orbiculoidea lodiensis fauna, and the limestone nodules were called the Lodi Limestone by Clarke (in Lincoln, 1897, p. 100). Lincoln's "Lodi Limestone" was correlated by Luther (1909, p. 27) with beds identified as "Genundewa" at Fir Tree Point $(\mathrm{Wg}-3)$ because of faunal similarities and because both were at the top of the black-shale sequence. This correlation implied that Lincoln's limestone at Lodi was equivalent to the Genundewa at Canandaigua Lake, whereas our sections show that the nodular limestone in Mill Creek at Lodi is at least 195 feet below the horizon of the Genundewa, which at Lodi is represented by the sparsely fossiliferous Crosby Sandstone of Torrey and others (1932). Because several well-known faunal zones, such as the Reticularia laevis zone of William (Williams and others, 1909) near Ithaca, occur in the stratigraphic intervals between beds containing the Orbiculoidea lodiensis fauna and the GenundewaCrosby bed, paleontologic studies in which the Genundewa fauna has been equated with the Orbiculoidea lodiensis fauna should be reevaluated.

The upper boundary of the Penn Yan Shale Member from Buffalo Creek (Dp-2), Erie County, east to the vicinity of Shuman Cemetery $(\mathrm{Ph}-5)$, Ontario County, and Corry Gully (Nap-5), western Yates County, is at the base of the thin sheet of the styliolinid Genundewa Limestone Member. The top of the Penn Yan probably closely approximates a time line across this part of western New York. From the western side of Keuka Lake eastward, the top of the Penn Yan is placed at the base of an eastward-thickening sequence of siltstone, the combined Ithaca, Renwick Shale, and Sherburne Flagstone Members (pls. 3 and 5). A lower tongue of Penn Yan extends far to the east and interfingers with the Sherburne Flagstone Member in the vicinity of Tully, Onondaga County. The middle and upper parts of the Penn Yan interfinger with the Sherburne Flagstone, Renwick Shale, and Ithaca Members between Keuka and Cayuga Lakes (pls. 3 and 5). Consequently, the top of the Penn Yan is placed at progressively older stratigraphic positions to the east. In contrast to the close approach to a time line west of Keuka Lake, the top of the Penn Yan is sharply diachronic to the east.

\section{SHERBURNE FLAGSTONE MEMBER}

Vanuxem $(1840$, p. 381$)$ proposed the name Sherburne for the sequence of silty and sandy rocks 
above the black shale that overlies the Tully Limestone in the vicinity of Sherburne, Chenango County. In 1959, we (de Witt and Colton, 1959, p. 2821; fig. 2 and 4 ) excluded the Sherburne from the Portage Formation as used by Williams and others $(1909$, p. 5$)$ and assigned it a member status in our Genesee Formation.

From Tully west to the vicinity of Ithaca and Cayuga Lake, the Sherburne is composed largely of thin-bedded to massive laminar light-gray (N7) siltstone, and some silty shale, shaly siltstone, and a few beds of very fine grained sandstone. Commonly, the bedding ranges from an inch to 1 foot in thickness, but locally some massive beds exceed 15 feet. Many of the thicker beds are structureless or slightly laminated in the basal part and ripple marked near the top. Commonly, the base of the siltstone bed is sharp, whereas the top is gradational into the thin shaly parting above. Sole markings are conspicuous on the base of many beds, and small-scale cut-and-fill structures are locally abundant. The Sherburne shows depositional features characteristic of a turbidite accumulation. Sequences of thick or thin beds appear to have some lateral continuity, but individual beds generally cannot be correlated in adjacent sections with certainty.

The Sherburne Flagstone Member is present overlying the Penn Yan Shale Member from the Tully quadrangle west to the ridge between Cayuga and Seneca Lakes where it intertongues with and grades laterally into the silty mudrock and shale of the Penn Yan Shale Member (pls. 3 and 5). The Sherburne is about 155 feet thick near Kelloggsville (Sk-1), 110 feet thick at Glenwood Creek (I-1) northwest of Ithaca, where we designated a reference section for the member (de Witt and Colton, 1959, p. 2821), and about 45 feet thick at Sheldrake Creek (Gen-1). The Sherburne is not a recognizable unit at Mill Creek near Lodi $(\mathrm{Ov}-10$, pl. 3). About 40 feet of the Sherburne is present in a drill core (WG-Ch) cut near Corbett Point north of Watkins Glen on the west side of Seneca Lake, and some of the top of the member is exposed below a 2- to 3-foot massive siltstone, horizon " $\mathrm{S}$ " of Bradley and Pepper (1938, p. 11) in Quartermile Creek (Wg-12) and Excelsior Glen $(\mathrm{Wg}-17)$ at the south end of Seneca Lake. Subsurface data are scant, but the isopach of the Sherburne Flagstone Member (fig. 5) shows the member to be more than 250 feet thick in parts of Cortland and Tioga Counties. The abrupt thinning of the wedge of Sherburne in the vicinity of Cayuga Lake marks the zone where the distal edge of the Sherburne turbidite fan interfingers with the Penn Yan. The Sherburne can be identified with certainty in the subsurface only where the overlying Renwick Shale Member is definitely present. Elsewhere, it cannot be separated from the overlying Ithaca Member.

Fossils are not abundant in the Sherburne in most of its extent in the study area, although locally they may be found in moderate numbers. The first Reticularia laevis zone of Williams (Williams and others, 1909, p. 6) is found in the upper 35-40 feet of the member at Renwick Brook (I-10) and at Willow Point Gully (I-11).

The Sherburne Flagstone Member is overlain by the Renwick Shale Member of the Genesee Formation from Threemile Point Gully (Sk-3, pl. 3) west across the area. The upper boundary of the Sherburne is the base of the oldest bed of brownishblack $(5 Y R 2 / 1)$ or very dark olive gray $(5 Y 3 / 1)$ shale in the Renwick Shale Member. Locally, as at Glenwood Creek (I-1) and Buck Corners Creek (Gen-8), the contact is clearly defined; elsewhere, as at Sheldrake Creek (Gen-1), the top of the Sherburne is difficult to identify (pl. 3).

\section{RENWICK SHALE MEMBER}

At Cayuga Lake, the Sherburne Flagstone Member is overlain by a 5 - to 45 -foot sequence of grayish-black (N2), brownish-black $(5 Y R 2 / 1)$ to very dark olive-gray $(5 Y 3 / 1)$ iron-stained shale containing an abundance of siltstone-filled scour channels. Near Ithaca, this sequence of dark shaly strata was informally named Ithaca Lingula shale by Williams (1906, p. 592) and was apparently designated as the Renwick Shale Member of the Middlesex Shale Formation by Caster (1933, p. 202). Because Caster's Renwick was proposed in an abstract, the type section and boundaries of the unit were not described. Our study (de Witt and Colton, 1959, p. 2821 and fig. 4) clearly showed that the Renwick was not a part of the Middlesex Shale Member of the Sonyea Formation, Caster's Middlesex Shale Formation. We redefined the Renwick as a member of the Genesee Formation and selected outcrops in Renwick Brook (I-10) north of Ithaca as the type exposure of the member.

The Renwick Shale Member is present at Threemile Point Gully (Sk-3) and Scott Gulf (Mor-5) south of Skaneateles Lake, where it consists largely of very dark brown $(5 Y R 3 / 1)$ to dark-olive-gray $(5 Y 3 / 1)$ iron-stained silty shale containing a scattering of scour channels filled with medium- to light-gray (N5 to N6) siltstone. Individual chan- 


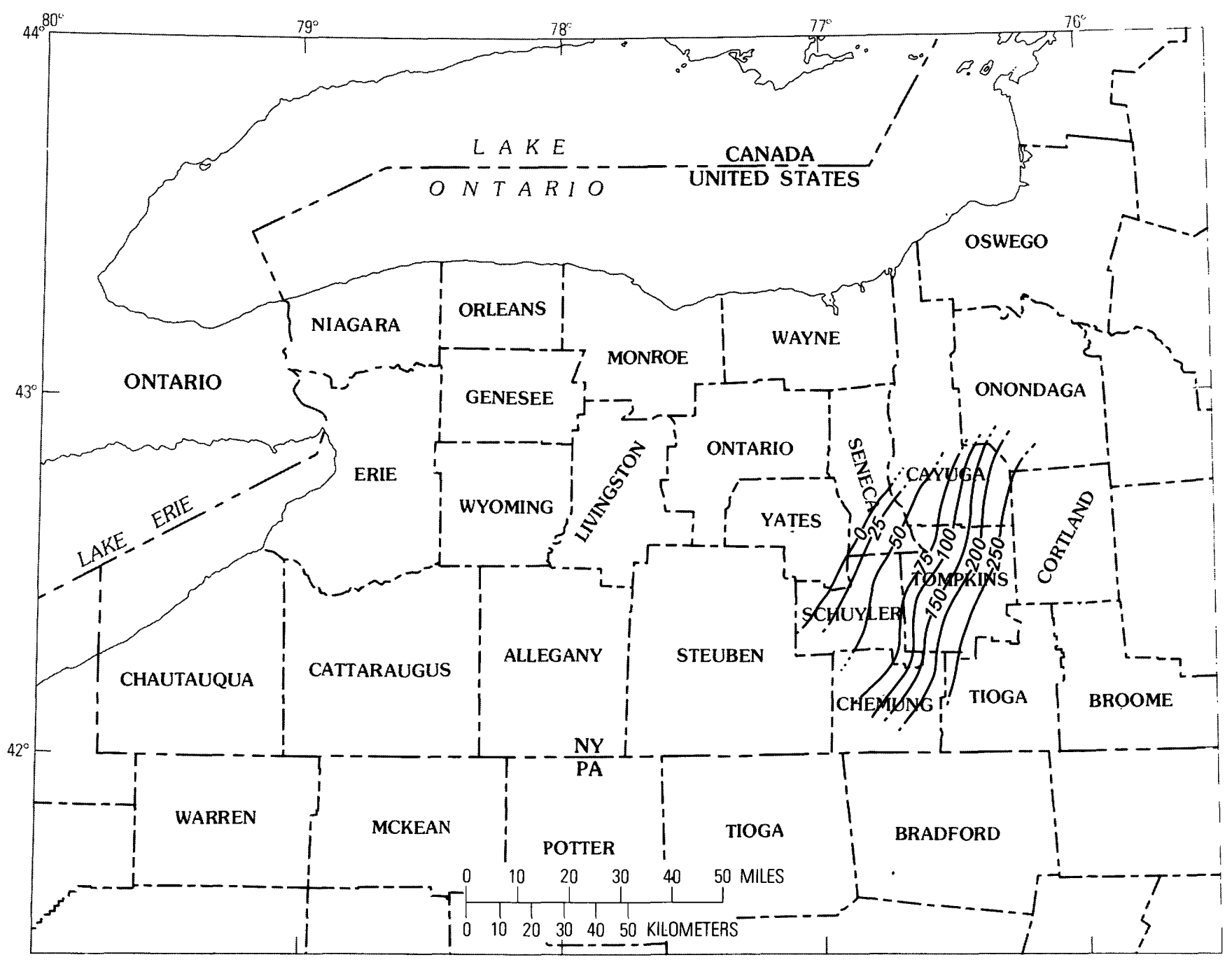

FIGURE 5.-Isopach map showing thickness of the Sherburne Flagstone Member in feet.

nels may be as much as 3 feet deep and 30 feet wide. Channel filling may pinch out at the edge of the channel or merge into a sheet of laminated or ripplebedded siltstone. In much of the area between Skaneateles and Owasco Lakes, the dark shale in the Renwick is not as conspicuous as in the member west of Cayuga Lake, and the Renwick can best be identified by the abundance of siltstone-filled scour channels.

The Renwick is about 45 feet thick at Threemile Point Gully (Sk-3) and thickens to more than 60 feet near Ithaca (I-3). In the vicinity of Ithaca, the amount of brownish-black (5YR 2/1) and very dark gray (N2 to N3) rock increases considerably, and the number of scour channels reaches a maximum. Scant data indicate that the greater number of channels trend southwest and have current flow from east to west (fig. 6); although some channels show current flow to the east.
Between Cayuga and Seneca Lakes the Renwick Shale Member thins relatively abruptly, and the amount of intercalated siltstone also decreases. The Renwick is composed mainly of very dark gray (N2) and brownish-black (5YR 2/1) shale containing a few laminae or stringers of siltstone on the west side of Seneca Lake (Ov-3 to $\mathrm{Wg}-9, \mathrm{pl} .5)$, where the nember is generally less than 10 feet thick. The isopach of the Renwick Shale Member (fig. 7)) shows a linear maximum of more than 60 feet in western Tompkins and eastern Chemung Counties. The member thins rather rapidly to the northwest, except for a local protuberance from the area of greatest thickness across part of western Tompkins County to the southern part of Seneca Lake.

We traced the westward-thinning Renwick into the type area of the Penn Yan Shale Member (Py13 and $P y-13)$ at Keuka Lake outlet and to Sart- 


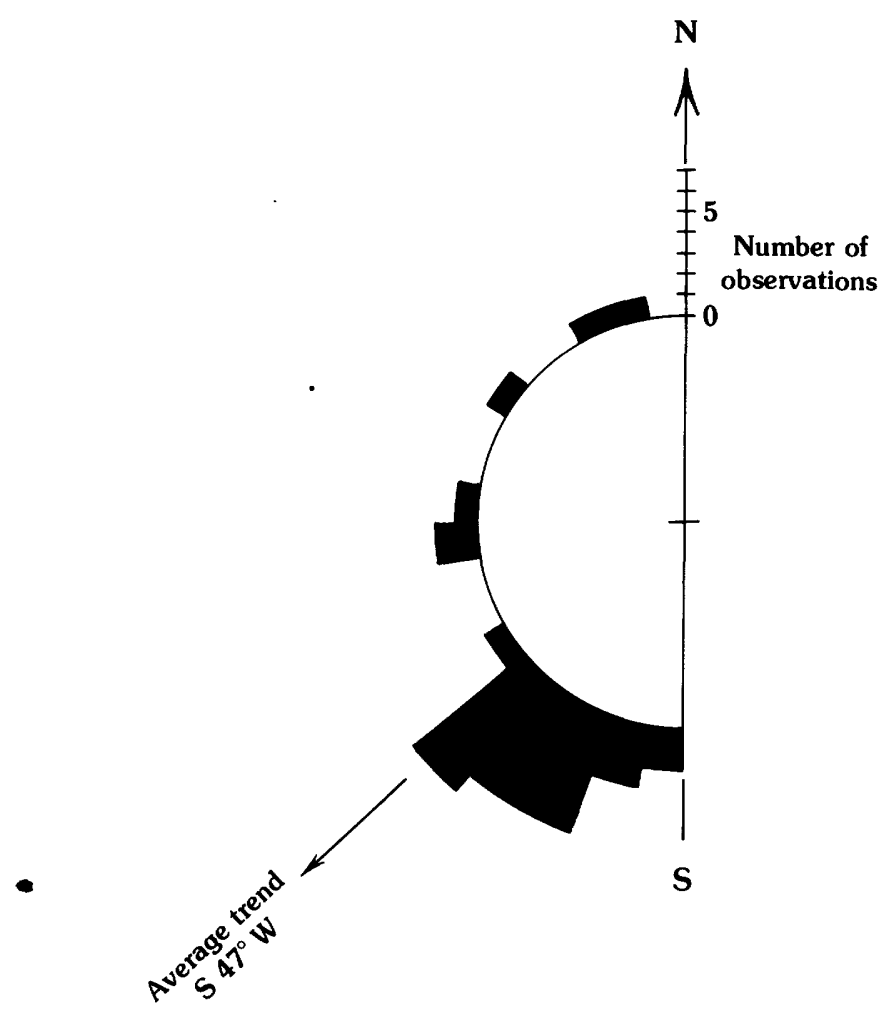

Figure 6.-Diagram showing trends of siltstone-filled scour channels in the Renwick Shale Member based on 31 observations at 11 localities east of Seneca Lake.

well Ravine (Py-i1) south of Penn Yan where the Renwick consists of 6-8 feet of brownish-black $(5 Y R 2 / 1)$ iron-stained fissile shale in the middle of the Penn Yan. Most probably the Renwick is equivalent to one of the thinner beds of black shale in the Penn Yan farther west, but we were unable to establish a positive correlation west of Keuka Lake.

At Cayuga Lake, the Renwick Shale Member is sandwiched between massive siltstone units, the Sherburne Flagstone Member below and the Ithaca Member above (pl. 3). Between Cayuga and Seneca Lake, the Sherburne grades laterally and interfingers into the shaly Penn Yan and the base of the Ithaca Member rises stratigraphically to the northwest. At Quartermile Creek at Watkins Glen ( $\mathrm{Wg}$ 12), siltstone and silt shale of the Ithaca cap the Renwick (pl. 5), whereas near Lodi (Ov-10), 15 miles to the north, about 25 feet of Penn Yan separates the Renwick from the younger Ithaca. Along Keuka Lake outlet (Py-12 to Py-13), as much as 75 feet of Penn Yan shaly strata separates the Renwick from the Ithaca.
A second extensive bed of dark-brownish-gray (5YR 2.5-3/1) iron-stained shale is present stratigraphically higher in the Penn Yan Shale and Ithaca Members in the vicinity of Seneca Lake. This bed of dark shale, here informally named the "Starkey" black bed "Stb," is typically exposed in the stream east of Starkey (Ov-6) where the bed is about 9 feet thick. Recognition of the presence of two units of iron-stained dark-brownish-gray to grayish-black shale in the upper half of the Penn Yan and equivalent beds around Seneca Lake is essential to working out the local stratigraphy ( $\mathrm{Py}-11$ to $\mathrm{Wg}-13, \mathrm{pl} .5$; and $\mathrm{Ov}-10$ to Gen-5, pl. 3), particularly along the west side of Seneca Lake, where locally the Renwick dips below lake level near Glenora Falls $(\mathrm{Wg}-1)$ and in the vicinity of Salt Point (Wg-11).

Throughout much of its extent, the Renwick Shale Member is unfossiliferous. However, at Renwick Brook (I-11) and in adjacent sections, the Renwick contains Lingula, Leiorhynchus, and Pluminaria plumaria in considerable numbers.

The upper boundary of the Renwick is much less distinct than the lower throughout most of the area east of Seneca Lake. Commonly, we place the upper boundary at the top of the youngest siltstonefilled channel in the sequence of interbedded dark shale and intercalated siltstone (pl. 3). Obviously, this boundary is not at the same stratigraphic position throughout the area. West of Seneca Lake, where the Renwick is within the Penn Yan, both top and base are sharply defined by the change in color from grayish or brownish black (N2 or $5 Y R$ $2 / 1$ ) of the Renwick to the medium olive gray ( $5 Y$ 5/1) of the Penn Yan (pl. 5).

\section{ITHACA MEMBER}

The Renwick Shale Member is overlain eastward from Seneca Lake by an eastward-thickening wedge of siltstone, silty shale, and silty mudrock. This mass of silty rock makes up the Ithaca Group of Hall $(1839$, p. 318-325) and much of the Ithaca Shale Member of the Portage Formation as used by Williams and others $(1909$, p. 6). In 1959 , we restricted the name Ithaca to the silty rocks between the Renwick Shale Member below and the West River Shale Member above in the area of Cayuga Lake. Because much of the member is nonshaly rock in this area, we deleted the descriptive term "shale" from the member name.

The Ithaca Member is composed largely of medium- to light-gray ( $N 5$ to N7), tan-weathering ( $5 \mathrm{Y}$ $6 / 4)$, slightly argillaceous medium- to coarse- 


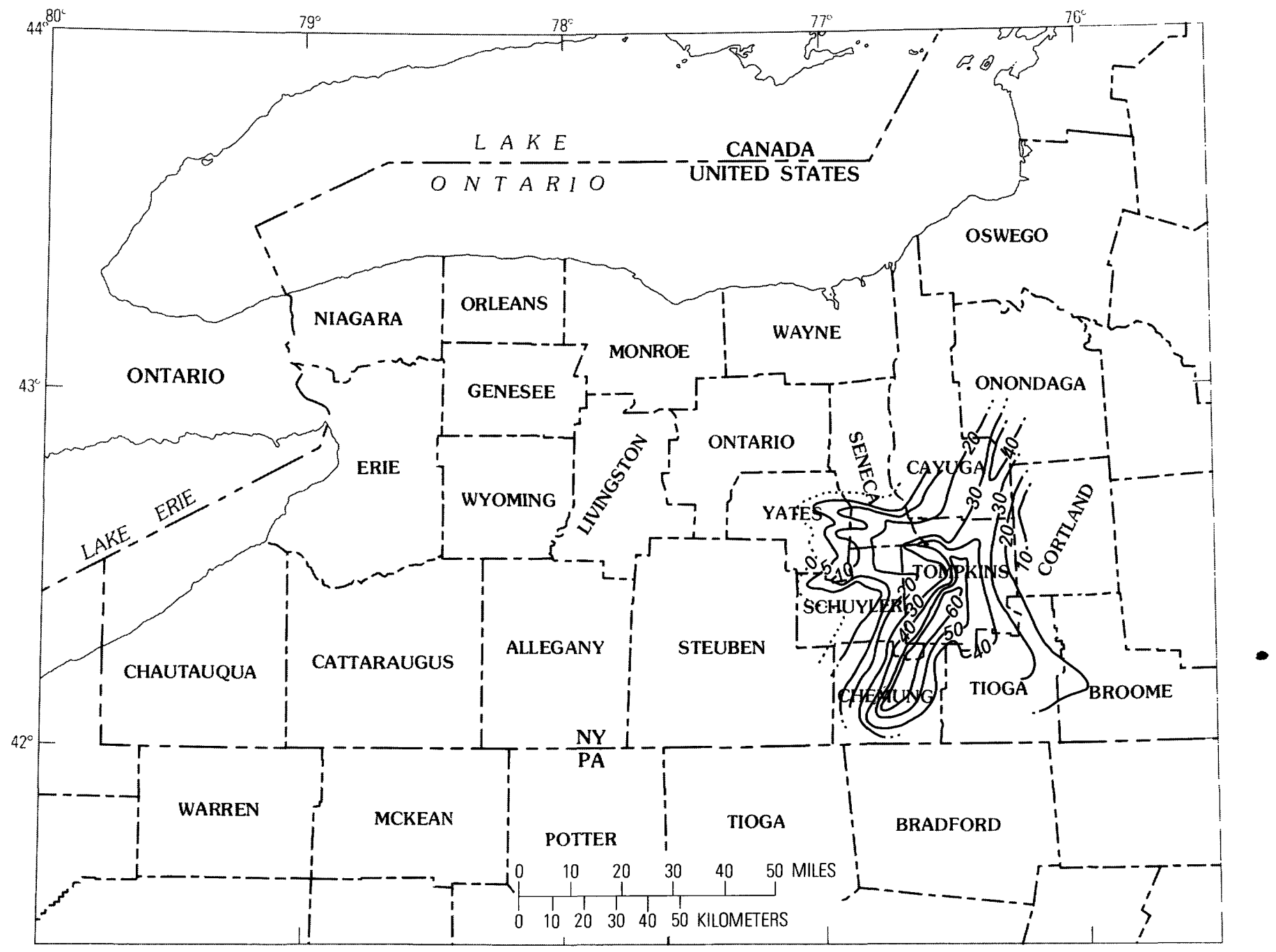

FIGURE 7.-Isopach map showing thickness of the Renwick Shale Member in feet.

grained quartzose siltstone, which locally contains some very fine to fine-grained quartz sandstone. Medium-gray (N5) to greenish-gray (5GY 5/1) silt-shale, shaly siltstone, silty shale, and silty mudrock are found in subordinate amounts. A few beds of dark-gray (N3) to brownish-black (5YR 2/1) commonly iron-stained shale and scattered beds of silty coquinoidal limestone are intercalated in the Ithaca.

Most of the siltstones in the Ithaca Member are turbidites. Bedding ranges in thickness from laminae less than 0.1 inch to more than 10 feet. Many beds have a discrete base and an irregular or indefinite top. They show basal-graded, lower laminated, and current-rippled divisions similar to those of the turbidites in the Sonyea Formation (Walker and Sutton, 1967, p. 1013). Many of the thicker beds show both parallel laminations and complex crosslaminations, whereas the thinner layers may be largely ripple bedded. Sole markings are abundant, and small-scale current scours and cut-and-fill structures are common mainly in the eastern part of the area. Some of the more massively bedded siltstone contains subspheroidal to lenticular calcareous nodules as much as 2 feet thick and 4 feet long. Locally, lenses of silty coquinoidal limestone or lenses of broken fossils are intercalated in the member. Commonly, sequences as much as 25 feet thick of thick-bedded to massive siltstone are intercalated in somewhat thicker zones of thin-bedded siltstone, silt-shale, and silty mudrock. Although individual beds may have considerable lateral extent, the individual zones of massively bedded siltstone are generally lenticular and do not have regional continuity. An exception to this statement is the Crosby Sandstone. of Torrey and others (1932), whose regional continuity we demonstrated in 1959.

The Ithaca Member is about 450 feet thick in 


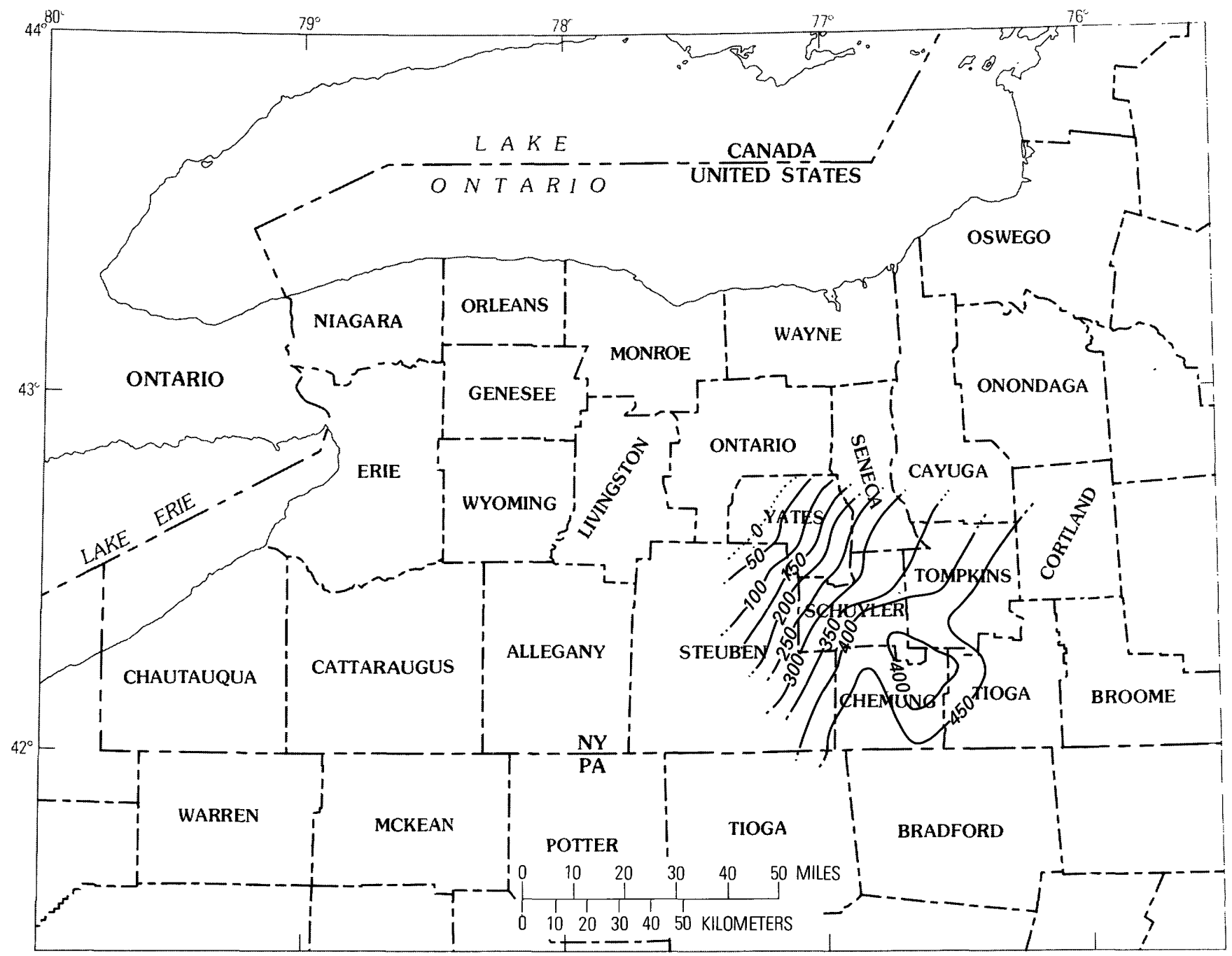

Figure 8.- Isopach map showing thickness of the Ithaca Member in feet.

the vicinity of Ithaca (Lick Brook, I-8; Willow Point, I-11) and only about 30 feet thinner at Watkins Glen (Wg-14) at the south end of Seneca Lake. The member thins to the northwest and is about 275 feet thick at Lodi $(\mathrm{Ov}-10)$ on the east side of Seneca Lake and about 200 feet thick at Plum Point Creek $(\mathrm{Ov}-3)$ near Himrod. The Ithaca is about 100 feet thick at Penn Yan $(\mathrm{Py}-10)$. The member is recognizable as far west as Chidsey Point Gully (Py-7, pl. 6) and intertongues and grades laterally into the West River Shale Member between Penn Yan (Py-10) and West River valley. The Ithaca is not a recognizable unit in sections at Voak (Py-2) and Shuman Cemetery ( $\mathrm{Ph}-5$, pl. 4) .

The Ithaca Member thickens east of Ithaca, but outcrop data are scant in this part of the study area. The great width of outcrop belt of the Genesee Formation, the lack of long continuous exposures, and the absence of identifiable key beds in the
Ithaca east of Tompkins County prevent an accurate determination of the thickness of the Ithaca in this area.

The isopach map of the Ithaca Member (fig. 8) shows thickness of more than 450 feet in eastern Chemung and western Tioga Counties. Subsurface data are virtually absent to the east in eastern Tioga, Broome, and Cortland Counties, thus preventing an accurate determination of the thickness of the member in the southeastern corner of the study area. In the subsurface, the Ithaca thins to the northwest from Ithaca and Watkins Glen to a zero line some place in central Yates County, northwest of Penn Yan. The general configuration of the wedge of Ithaca rocks suggests deposition from a southeastern source in contrast to a more easterly source for the older Sherburne Flagstone Member.

In contrast to many of the more massive siltstones in the Ithaca which are lenticular and of 
local extent, the Crosby Sandstone of Torrey and others (1932), a 3- to 10-foot thick massive unit of coarse-grained siltstone and some very fine grained sandstone, is a key unit of great areal extent. We traced this unit from Penn Yan (Py-10) east and southeast to Watkins Glen $(\mathrm{Wg}-14)$ and to the vicinity of Ithaca (I-8, pl. 5). It forms the basal beds of the Ithaca Member along Keuka Lake outlet east of Penn Yan (Py-11 and $\mathrm{Py}-12)$ and along the east arm of Keuka Lake south of Penn Yan to Sunset Point Gully (Py-16, pl. 4). Originally, the Crosby was described by Fox (1932) as being exposed near the community of Crosby south of Penn Yan on the east side of Keuka Lake. Bergin (1964, p. 12) found that the hamlet of Crosby had been moved about a mile between 1932 and 1964, and highway construction covers much of the exposure seen by Fox at the former site of Crosby. Consequently, the Crosby of Torrey and others (1932) is not exposed in Crosby Gully (Py-17), because the south dip places the unit below lake level. Although their Crosby is not exposed at Crosby Gully, it is a strongly erosion-resistant unit that is exposed at many places south and east of Penn Yan.

During the course of our work, W. H. Hass identified his Genundewa conodont fauna in the Crosby of Torrey and others (1932) near Penn Yan and later at other localities to the east and south as we projected its stratigraphic position toward Watkins Glen and Ithaca. Ultimately, we established their Crosby as a datum from Penn Yan to Ithaca through the thick and relatively indivisible sequence of silty rocks of the Ithaca Member (pls. 3,4 , and 5 ).

Although the Ithaca is relatively unfossiliferous, locally some beds contain moderate numbers of fossils, particularly in the eastern part of the area. One of the more spectacular accumulations of fossiliferous material is the Williams Brook coquinite member of Caster (1933, p. 202) a 10-foot-thick interval of shell fragments intercalated in the sequence of thick-bedded to massively bedded siltstone. The Williams Brook coquinite is about 70-80 feet below Torrey's Crosby Sandstone and about 165 feet above the base of the Renwick Shale Member at Williams Brook. At this site beds that consist of cross-laminated shell fragments and that are as much as 3 feet thick form a small waterfall. We were unable to locate similar accumlations of fossils at the same horizon in adjacent sections.

In the lower part of the Ithaca Member at Big Stream $(W g-1)$, a bed of calcareous siltstone con- taining many small fossils was identified by Clarke and Luther $(1905$, p. 11) as the Parrish Limestone Lentil of Cashaqua Shale. This bed is a local fossiliferous siltstone, which is about 30 feet above Torrey's Crosby Sandstone. The true Parrish Limestone Lentil of the Cashaqua of Clarke and Luther (1904, p. 31-32) crops out within the Cashaqua Shale Member of the Sonyea Formation farther west in Big Stream at a much higher elevation.

In the area east of Seneca Lake, where the Ithaca Member overlies the Renwick Shale Member, the lower boundary of the Ithaca is arbitrarily placed at the top of the youngest siltstone-filled channel in the sequence of dark shale and intercalated siltstone that composes the Renwick. West of Seneca Lake, the Ithaca overlies the Penn Yan Shale Member. The base of the Ithaca is marked by thickbedded to massive siltstone or the Crosby Sandstone cf Torrey and others (1932) on a sequence of medium-gray mudrock containing subordinate amounts of black shale and many calcareous nodules (pls. 3, 4, and 5).

The upper boundary of the Ithaca is arbitrarily placed at the top of the youngest sequence of thickbedded Ithaca-type siltstone above which the sequence is largely composed of shale and mudrock of the West River Shale Member. The top of the Ithaca is diachronous and becomes younger to the south and southeast from Penn Yan to Watkins Glen and Ithaca (pls. 3 and 5). Locally along Seneca Lake north of Watkins Glen, a tongue of massive Ithaca-type siltstone is found in the upper part of the West River Shale Member not far below the base of the Middlesex Shale Member, the basal member of the Sonyea Formation. This tongue of siltstone is horizon "MF" of Bradley and Pepper $(1938$, p. 12$)$, which they originally assigned to a position above the Middlesex rather than below the member.

East of Ithaca, across the Dryden and Harford quadrangles, data are scant. The top of the Ithaca appears to rise stratigraphically in the section, although the West River Shale Member is thick in the central and eastern parts of the Dryden quadrangle. Many beds of siltstone occur in the West River Shale Member in this area, and differentiation of the Ithaca from the West River becomes increasingly difficult to the east. In eastern Tioga and western Broome Counties in the Harford quadrangle, Ithaca-type siltstones are found not far below the basal brownish-black shale of the Middlesex Shale Member. Although the data are scant for want of long continuously exposed sections in 
the upper part of the Genesee Formation, the Ithaca Member appears to be the upper member of the Genesee Formation along the east side of the Tioughnioga River valley. The West River Shale Member appears to have graded laterally and intertongued with the Ithaca Member along the eastern border of the study area.

\section{GENUNDEWA LIMESTONE MEMBER}

The Genundewa Limestone Member of the Genesee Formation (de Witt and Colton, 1959, p. 2818) was originally named the Genundewa Limestone by Clarke (1903, chart) and later was redesignated the Genundewa Limestone Lentil of the Geneseo Shale by Bradley and Pepper $(1938$, p. 9$)$. Our work demonstrated that the Genundewa was not a lentil in Chadwick's Geneseo Shale, and we changed the Genundewa to member status in the Genesee Formation, although, because it is extremely thin in comparison with other members of the Genesee, it cannot be mapped at a scale of $1: 24,000$. The Genundewa is typically exposed at Genundewa Point (Nap-4) at the southwest end of Bare Hill, known locally as "Genundewah" or Genundewa Hill, on the east side of Canandaigua Lake.

As originally defined by Clarke (1903) and as redefined by us in 1959, the Genundewa at its type locality consists of a 12- to 15-foot-thick sequence of dark-gray ( $N 3$ to $N 4$ ) calcareous shale and mudrock containing many nodules of very dark gray to black (N3 to N2) argillaceous limestone from 1-10 inches thick, several beds of grayish-black (N2) to brownish-black (5YR 2/1) slightly silty shale, and several zones of spheroidal to discoidal limestone nodules as much as 8 inches thick and $11 / 2$ feet in diameter. The uppermost bed of limestone is composed largely of the shells of the minute pteropodlike Styliolina fissurella set in a matrix of calcilutite. Styliolina is much less abundant in the calcareous beds and nodules below.

We are here further restricting the Genundewa to only the relatively thin bed of styliolinid limestone at the top of the 12- to 15- foot-thick sequence heretofore identified as Genundewa at Genundewa Point (Nap-4). The remainder and much larger part of the sequence is hereby included in the Penn Yan Shale Member of the Genesee Formation. Detailed sections and microcorrelations indicate that the sheet of styliolinid Genundewa extends as a single unit ranging in thickness from 0.1 to 2 feet from the shore of Lake Erie one-half mile west of the mouth of Pike Creek (SC-1) east to the vicinity of Corry Gully (Nap-4) and Shuman Cemetery $(\mathrm{Ph}-5)$, a distance of about 95 miles (pls. 2 and 4).

Throughout its extent, the Genundewa consists of one or more layers of grayish-black (N2) to dark-olive-gray $\left(\begin{array}{ll}5 Y & 3 / 1\end{array}\right)$ slightly argillaceous, slightly silty, dense styliolinid limestone in which shells of Styliolina fissurella may make up as much as 70 percent of the rock. Locally, some layers contain small pellets or pseudo-oolites. Freshly broken surfaces of the Genundewa have a speckled glistening surface produced by the calcite filling of the randomly oriented pteropod shells. The Genundewa generally weathers to sheets, nodules, and slabby cobbles of light-gray or tan-surfaced limestone. Bedding is irregular, undulose, or nodular. In general, the basal surface of the member is more irregular than the top. At many places, large discoidal nodules as much as 0.6 foot thick and 1-2 feet in diameter occur in the upper part of the Penn Yan just below the Genundewa, and the Genundewa bed is slightly arched over the centers of the nodules. Locally, many small spheroidal or discoidal nodules are found in the Genundewa, and at many places, particularly east of Canandaigua Lake, lenticular laminae and stringers of quartz silt as much as 0.05 inch are present in the member.

Although rarely more than 1 foot thick, the Genundewa has a characteristic lithology that makes it an easily identified key bed. Because of its superior resistance to erosion in comparison with the soft enclosing shale and mudrock, the Genundewa caps small falls and riffles in tributary creeks and locally caps some spectacular falls ( $\mathrm{Cl}-4)$.

The Genundewa Limestone Member can be traced readily from Lake Erie east to Corry Gully (Nap5 ) in the West River valley east of Canandaigua Lake. Although data are scant between Corry Gully and the gully at Penn Yan (Py-10), the solid sheet of Genundewa at Corry Gully appears to thin and to grade laterally into a digitate sequence of lenses of silty argillaceous styliolinid limestone intercalated with some calcareous silty shale, with siltstone laminae, and a scattering of medium to large discoidal silty nodules in the vicinity of Shuman Cemetery (Ph-5, pl. 4). Exposures of the Genundewa interval are scarce between Shuman Cemetery and Penn Yan (Py-10), but physical and paleontologic data show that the Genundewa Limestone Member is essentially the stratigraphic equivalent of the Crosby Sandstone of Torrey and others (1932) at Penn Yan (pl. 4). Actually, the featheredge of their Crosby may be the thin siltstone capping the 
irregular bed of silty styliolinid Genundewa near Shuman Cemetery $(\mathrm{Ph}-5)$ and the thin siltstone laminae in the upper part of the Genundewa at Corry Gully (Nap-5).

Correlation of the Genundewa Limestone Member with the Crosby provides a datum between Lake Erie and Ithaca that crosses several facies and divides the Genesee Formation vertically into about equal parts (pls. 2, 3, and 4).

The Genundewa Limestone Member is probably the most fossiliferous member in the Genesee Formation, in spite of its relatively slight thickness. In addition to the numerous styliolinids, the Genundewa contains many conodonts, a fairly large fauna of invertebrate macrofossils, some fish bones and teeth, and a scattering of plant fossils. The sea at the time the Genundewa accumulated must been swarming with life, at least in the upper part of the water column, and the adjacent land area was covered in part with primitive terrestrial plants.

Commonly, the upper boundary of the Genundewa is sharply defined by the abrupt change from styliolinid limestone to dark-gray slightly calcareous shale containing some siltstone laminae. At many places, the basal bed of the West River Shale Member is a slightly calcareous dark-gray (N4) argillaceous siltstone as much as half an inch thick. At other localities, medium-gray $(N 5)$ to very dark olive-gray $(5 Y 3 / 1)$ shale lies directly upon the slightly undulose upper surface of the Genundewa Limestone Member.

\section{WEST RIVER SHALE MEMBER}

Clarke and Luther $(1904$, p. 28) gave the name West River Shale to a sequence of shaly rocks above their Genundewa limestone and under their Standish flags and shales in West River valley about 3 miles east of Canandaigua Lake. We found that the Standish flags and shales of Clarke and Luther are not lithologically different from much of the West River strata below. In 1959, we (de Witt and Colton, 1959, p. 2819) redesignated the West River a member of our Gensee Formation and included the Standish in our redefined West River Shale Member.

The West River Shale Member is composed largely of dark-gray (N4) to medium-light-gray (N6) shale and mudrock. The strata become more silty eastward, and thin-bedded light-gray shaly siltstone is common in the member east of Ithaca. Many relatively thin beds of grayish-black (N2) to dark-olive-gray $(5 Y 3 / 1)$ iron-stained shale an inch to several feet thick are intercalated in the member, especially in the area west of Seneca Lake. Because these individual black beds have great lateral continuity, they are excellent key beds for widespread correlation (pls. 2, 4, and 6). Many layers of spheroidal to discoidal grayish-black (N2) argillaceous, slightly silty limestone nodules 1 inch to 2 feet thick and 6 inches to 4 feet in diameter are present in the West River. Commonly, the layers or zones of nodules are associated with beds of black shale and are useful for correlation of adjacent sections (pl. 4). Several layers of grayish-black (N2) bituminous to medium light-gray (N6) slightly calcareous siltstone are intercalcated in the member west of Keuka Lake. Siltstones become thicker bedded and more numerous in the West River Shale Member east of Keuka Lake, although they do not become a major constituent of the member in the area west of Ithaca.

The West River Shale Member is about 8 feet thick in the vicinity of the mouth of Pike Creek (SC-1) at Lake Erie. The member thickens eastward to about 53 feet on the west side of the Genesee valley (Cl-1, Cl-3, pl. 6) and is about 132 feet thick at Seneca Point Gully (Nap-1), the reference section for the member (de Witt and Colton, 1959, p. 2819). The West River thins to about 95 to 100 feet at Keuka Lake (Py-7 to $\mathrm{Py}-16, \mathrm{pl} .6)$ and is about 75 feet thick at Watkins Glen (Wg-14). It thickens to more than 130 feet near Ithaca (I-8, I-9) and may be as much as 200 feet thick in the north-central part of the Dryden quadrangle (Dy-5 and $\mathrm{Dy}-7$ ). The West River appears to thin to the east across the Harford quadrangle by intertonguing with the Ithaca Member and is less than 50 feet thick along the west side of the Tioughnioga Valley (Hf-7). The isopach of the West River Shale Member (fig. 9) shows an eastward-thickening wedge of rock with a maximum thickness of more than 200 feet in the vicinity of Van Etten in northeastern Chemung County. The area of thick West River appears to extend northeast to the thick sections in the north-central part of the Dryden quadrangle. The abrupt thinning of the West River across the Harford quadrangle cannot be demonstrated in the subsurface because of the lack of control.

The West River Shale Member contains some thin beds that have great lateral continuity. Of these beds, the Bluff Point Siltstone Bed (Bergin, 1964 , p. 13) is the most widespread. The Bluff Point Siltstone Bed, also known as the Keuka Flagstone of Fox (1932, p. 683) and the Bluff Point Flagstone Member of the Standish of Torrey and 


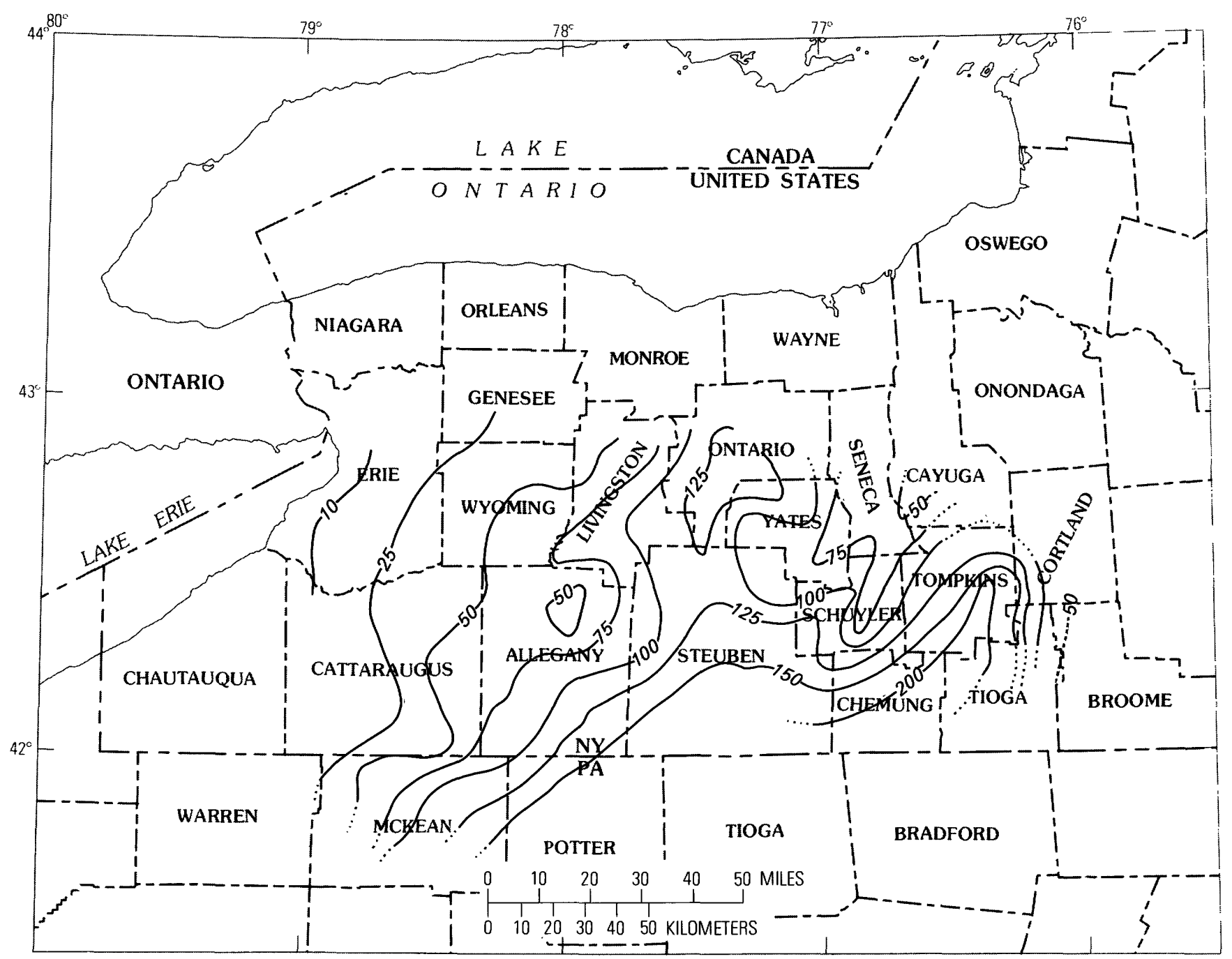

FIGURE 9.-Isopach map showing thickness of the West River Shale Member in feet.

others (1932, p. 16, figs. 6, 7), is a resistant, medium- to light-gray ( $N 5$ to N6) convolute-bedded siltstone 3-4 inches thick, which has a strongly ripple marked upper surface in outcrops around Keuka Lake. Because it is resistant to erosion, the Bluff Point Siltstone Bed commonly caps small falls and forms a riffle in broad creek beds. It is a fine key bed for local mapping (Bergin, 1964, p. 14). We traced the Bluff Point east to Plum Point Creek (Ov-3) west of Himrod and tentatively identified it on Mill Creek at Lodi $(\mathrm{Ov}-10$, pl. 3). The Bluff Point is present south along the west side of Seneca Lake to Big Stream-Glenora $(\mathrm{Wg}-1)$ and appears to merge into the upper part of the Ithaca between Big Stream and the creek at Reading Center (Wg-9, pl. 5). The Bluff Point loses its convolute bedding between Keuka Lake and Canandaigua Lake, where it is represented by a much crosslaminated quartzitic dark-gray (N4) siltstone about $11 / 2$ to 2 inches thick (Nap-5 and Nap-1, pl. 4). Correlation of the many beds of black shale and nodules in the West River Shale Member confirms the extension of the Bluff Point between Keuka and Canandaigua Lakes. The thin, resistant highly ripple marked dark-gray (N4) Bluff Point Siltstone Bed is present in most sections between Seneca Point Gully (Nap-1) at Canandaigua Lake and Eighteenmile Creek $(\mathrm{Ed}-1)$ southwest of Buffalo (pl. 2). The absence of the Bluff Point in the Honeoye quadrangle may be the result of nondeposition over a local high spot in the sea floor when the Bluff Point silt flushed across the sea bottom. The presence of this unique turbidite in the middle part of the West River Shale Member gives us a time line across western and central New York from Lake Erie to Seneca Lake. The Bluff Point Siltstone Bed is only slightly less extensive than the Genundewa-Crosby horizon. 
The Standish flags and shales of Clarke and Luther (1904, p. 29) consist of three beds of darkgray (N3) to dark-olive-gray (5Y 3/1) bituminous siltstone or very silty brownish-black shale $(5 Y R$ 2/1) about 1-3 inches thick and some associated limestone nodules, which occur in the upper 4 feet (Buck Run Creek, Nu-2) to 7 feet (Chidsey Point Gully, Py-7) of the West River Shale Member between the Genesee River and Keuka Lake. The three beds can be correlated fairly well between adjacent sections, but the siltstone and enclosing shale are not sufficiently different lithologically to warrant recognition as a discrete member. Other beds of siltstone or black shale in the West River have comparable areal extent.

The upper boundary of the West River Shale Member throughout most of the mapped area is the base of the brownish-black $(5 Y R 2 / 1)$ to oliveblack $(5 Y 2 / 1)$ fissile shale of the Middlesex Shale Member of the Sonyea Formation. The contact between the West River and the Middlesex is sharp throughout the mapped area (pls. 2, 3, and 5). In the extreme eastern part of the mapped area, where the east-thinning wedge of West River Shale Member intertongues with the Ithaca Member, the upper boundary of the Genesee Formation is clearly marked by the change from medium-dark-gray siltstone of the Ithaca into the dark-brownish-gray $(5 Y R 3 / 1)$ shale of the Middlesex.

\section{ENVIRONMENT OF DEPOSITION}

The sediments that make up the Genesee Formation in western New York accumulated in the eastern part of a wide and relatively shallow epicontinental sea covering much of the central United States during the Late Devonian. The sea lay west of a rising landmass that was the source for most of the detrital Genesee sediments. The large and growing Catskill Delta appended the source area and extended west into the sea. The rocks of the Genesee Formation in western New York are the distal facies of the deltaic wedge.

The abundant black, brownish-black, and very dark gray shale and mudrock in the lower part of the Genesee Formation are believed to have accumulated in a euxinic environment, in a sea so deep and quiet that the basal waters were deficient in oxygen much of the time. Presumaibly the black and brownish-black shales represent deposition in relatively tranquil water with a depositional energy level just sufficient to move fine-grained quartz, silt, clay, and macerated plant detritus but insufficient to sort and winnow them into discrete beds and layers of individual components.

The sea in which the lighter gray mud and silt of the Penn Yan and the West River accumulated appears to have been slightly better oxygenated. The numerous beds of siltstone in this part of the succession are largely free from carbonaceous detritus and indicate a level of depositional energy high enough to sort and winnow the fine-grained sediments. The overall vertical decrease in darker colors from the Geneseo through the Penn Yan and West River Shale Members indicates a general clearing of the Genesee sea, although brief recurrences of euxinic conditions are shown by the many stringers and beds of brownish-black or grayish-black mudrock or shale intercalated in the Penn Yan and West River. The Renwick Shale Member marks the presence of a widespread reducing environment in the vicinity of Seneca and Cayuga Lakes. Possibly some of the thinner and less extensive beds of black shale may indicate short episodes of extensive and prolific algal blooms and the resultant brief fouling of the sea and accumulation of abundant unoxidized plant remains on the sea floor. The relatively meager fauna in the dark mudrock and shale of the Genesee suggests an environment hostile to most benthonic forms. However, the presence of abundant Styliolina and other pelagic forms in the Genundewa Limestone Member and in other calcareous beds and associated shales suggests that at times the upper layers of the sea were well supplied with oxygen and nutrients.

The North Evans Limestone of Rickard (1964) is a lag deposit concentrated by relatively mild scour of the uppermost beds of the Hamilton Group in western New York. During this brief episode of erosion, most of the soft recently deposited muds were swept away, and conodonts, heavy minerals, and other relatively insoluble components from the eroded strata were concentrated on a broad shoal in extreme western New York. Possibly much of the erosion took place just before and during deposition of the lower part of the Tully Limestone in central New York and before the general quiesence of early Genesee time.

The Genundewa Limestone Member suggests depositional energy sufficient to winnow the accumulating detritus and to sweep away the fine-grained muds that would otherwise dilute the accumulating mass of Styliolina shells that were raining down from the upper layers of the Genesee sea. The apparent lack of preferred orientation of the shells suggests that the currents were not strong enough 
to reorient the shells when they came to rest on the sea floor.

The turbidite beds of the Sherburne Flagstone Member and the Ithaca Member indicate incursions of high-energy turbidity currents into the relatively tranquil deeper water of the Genesee sea. Distal turbidites, which make up much of the Sherburne at Cayuga Lake and much of the Ithaca west of Seneca Lake, indicate lower level of depositional energy than do the thicker and more proximal turbidites in the area east and southeast of Cayuga Lake. The distal turbidite beds are more sheetlike and lack basal channels incised in the subjacent strata. The presence of benthonic forms in local abundance and the evidence of many flow structures, including zones of flow rolls, in the upper part of the Ithaca Member in the vicinity of the Tioughnioga valley indicate the transition to proximal turbidites and a shift to a nearer shore high-energy environment.

Thus, the Genesee Formation shows an increase in depositional energy both vertically through the formation and laterally from west to east. The lateral change is considerably more conspicuous than the vertical change. Probably the most marked incursion of a turbidity flow is shown by the extent of the Bluff Point Siltstone Bed of the West River Shale Member far west of the general limit of Ithaca turbidites at Keuka Lake. The absence of other turbidites in the Penn Yan and West River Shale Members west of Keuka Lake suggests that the energy of most Ithaca turbidites was spent by the time the flows reached the vicinity of Seneca Lake and that turbidity flow ceased in the area between Seneca Lake and Canandaigua Lake. The presence of distal turbidites as much as a foot thick at Keuka Lake that are missing in the equivalent mudrock and shale at Canandaigua Lake strongly supports this conclusion.

\section{ROCKS ABOVE THE GENESEE FORMATION}

\section{SONYEA FORMATION}

The Middlesex Shale Member of the Sonyea Formation (Colton and de Witt, 1958) overlies the Genesee Formation throughout the study area. The Middlesex is composed of grayish-black (N2), brownish-black (5YR 2/1), and olive-black shale $(5 Y 2 / 1)$ in the area from Lake Erie to Seneca Lake. Locally, discoidal to enlongate ellipsoidal silty grayish-black (N2) limestone nodules 1 foot thick and 2-5 feet long are intercalated in the basal part of the Middlesex Shale Member. Dark- to medium- gray (N4 to N6) argillaceous to quartzitic siltstone is present in the member east of Seneca Lake. The beds of siltstone increase in number and thickness, particularly in the Dryden and Harford quadrangles. The Middlesex becomes silty and ranges in color from very dark gray (N3) to dark olive gray $(5 Y 3 / 1)$ in the Tioughnioga valley area. Fragments of plant fossils are locally abundant in the member in the vicinity of Marathon and Glen Aubrey. Flow rolls, small scour channels, and complex crosslaminations are common in the siltstone intercalated in the Middlesex east of Ithaca, and the number and size of the features increase to the east and are abundant near Glen Aubrey (Hf-5, 6, and 7).

\section{REFERENCES CITED}

Bergin, M. J., 1964, Bedrock geology of the Penn Yan and Keuka Lake quadrangles, New York: U.S. Geol. Survey Bull. 1161-G, 34 p.

Bradley, W. H., and Pepper, J. F., 1938, Structure and gas possibilities of the Oriskany sandstone in Steuben, Yates, and parts of the adjacent counties, Pt. 1 of Geologic structure and occurrence of gas in parts of southwestern New York: U.S. Geol. Survey Bull. 899-A, 68 p.

Caster, K. E., 1933, Upper Devonian rocks at Ithaca, New York [abs.]: Geol. Soc. America Bull., v. 44, no. 1, p. 201-202.

Chadwick, G. H., 1920, Large fault in western New York: Geal. Soc. America Bull., v. 31, no. 1, p. 117-120. 1933, Great Catskill delta and revision of late Devonic succession: Pan Am. Geologist, v. 60, no. 2, p. 91-107.

Clarke, J. M., 1903, Classification of New York series of geologic formations: New York State Mus. Handbook 19, 28 p. (chart and short text).

Clarke, J. M., and Luther, D. D., 1904, Stratigraphic and paleontologic map of the Canandaigua and Naples quadrangles [New York]: New York State Mus. Bull. 63, $76 \mathrm{p}$.

-1905 , Geology of the Watkins and Elmira quadrangles [New York]: New York State Mus. Bull. 81, 39 p.

Cole, W. S., and others, 1959, Guide book to the geology of the Cayuga Lake basin: Ithaca, N. Y., New York State Geol. Assoc., 31st Ann. Meeting, Cornell Univ., 36 p.

Colton, G. W., and de Witt, Wallace, Jr., 1958, Stratigraphy of the Sonyea formation of Late Devonian age in western and west-central New York: U.S. Geol. Survey Oil and Gas Inv. Chart OC-54.

Cooper, G. A., 1930, Stratigraphy of the Hamilton group of New York: Am. Jour. Sci., 5th ser., v. 19, p. 116-134, 214-236.

Cooper, G. A., and Williams, J. S., 1935, Tully formation of New York: Geol. Soc. America Bull., v 46, no. 5, p. 781-868.

de Witt, Wallace, Jr., and Colton, G. W., 1959, Revised correlations of lower Upper Devonian rocks in western and central New York: Am. Assoc. Petroleum Geologists Bull., v. 43 , no. 12 , p. $2810-2828$. 
Fox, I. W., 1932, Geology of part of Finger Lakes region, New York: Am. Assoc. Petroleum Geologists Bull., v. 16 , no. 7 , p. 675-690.

Goddard, E. N., and others, 1948, Rock-color chart: Washington, D.C., Nat'l. Research Council, 6 p. (repub. by Geol. Soc. America, 1951; reprinted 1971).

Grabau, A. W., 1917, Stratigraphic relationships of the Tully limestone and the Genesee shale in eastern North America: Geol. Soc. America Bull., v. 28, 945-958.

Grossman, W. L., 1944, Stratigraphy of the Genesee group of New York: Geol. Soc. America Bull., v. 55, no. 1, p. 41-76.

Hall, James, 1839, Third annual report of the fourth geological district [of New York] : New York Geol. Survey Ann. Rept. 3, p. 287-339.

-1840, Fourth annual report of the survey of the fourth geological distrct [of New York]: New York Geol. Survey Ann. Rept. 4, p. 389-456.

Heckel, P. T., 1973, Nature, origin, and signficance of the Tully Limestone: Geol. Soc. America Spec. Paper 138, $244 \mathrm{p}$.

Hinde, G. J., 1879, On conodonts from the Chazy and Cincinnati group of the Cambro-Silurian and from the Hamilton and Genesee shale divisions of the Devonian in Canada and the United States: Geol. Soc. London Quart. Jour., v. 35, p. 351-369.

Kirchgasser, W. T., 1975, Revision of Probeloceras Clarke, 1898 and related ammonoids from the Upper Devonian of western New York: Jour. Paleontology, v. 49, no. 1, p. 58-90.

Lincoln, D. F., 1897, Report on the structural and economic geology of Seneca County [New York]: New York State Geologist Ann. Report. 14, p. 57-125, map (1895).
Loomis, F. B., 1903, The dwarf fauna of the pyrite layer at the horizon of the Tully limestone in western New York: New York State Mus. Bull. 69, p. 892-920.

Luther, D. D., 1909, Geology of the Geneva-Ovid quadrangles [New York]: New York State Mus. Bull. 128, $41 \mathrm{p}$.

Rickard, L. V., 1964, Correlation of the Devonian rocks in New York State: New York State Mus. and Sci. Service, Geol. Survey, Map and Chart Ser. No. 4.

Sutton, R. G., 1951, Stratigraphy and structure of the Batavia quadrangle [New York]: Rochester Acad. Sci. Proc., v. 9, nos. 5-6, p. 348-408.

Torrey, P. D., Fralich, G. H., Young, W. H., Brewer, Charles, Jr., and Phillipi, P. M., 1932, The geology of New York and northern Pennsylvania: Am. Petroleum Inst., Div. Production, Paper 826-4A, 19 p.

Vanuxem, Lardner, 1839, Third annual report of the geological survey of the third district [of New York]: New York Geol. Survey Ann. Rept. 3, p. 241-285.

-1840 , Fourth annual report of the geological survey of the third district [of New York]: New York Geol. Survey Ann. Rept. 4, p. 355-383.

Walker, R. G., and Sutton, R. G., 1967, Quantitative analysis of turbidites in Upper Devonian Sonyea Group, New York: Jour. Sed. Petrology, v. 37, no. 4, p. 1012-1022.

Williams, H. S., 1906, Revision of the geologic section passing through Ithaca, New York: Jour. Geology, v. 14, p. 579-598.

Williams, H. S., Tarr, R. S., and Kindle, E. M., 1909, Description of the Watkins Glen-Catatonk district [New York]: U.S. Geol. Survey Geol. Atlas, Folio 169, 33 p. 